\title{
ANALISIS PENGEMBANGAN EKSPOR KOPI DI INDONESIA
}

\author{
Siska Fibriliani Sahat ${ }^{1}$, Nunung Nuryartono ${ }^{2}$, Manuntun Parulian Hutagaol ${ }^{2}$ \\ ${ }^{1}$ Mahasiswa Pascasarjana Ilmu Ekonomi, FEM IPB \\ ${ }^{2}$ Staff Pengajar FEM IPB
}

\begin{abstract}
This study aims to analyze recommendations that Indonesia could undergo to increase it's coffee export performance through factors influencing it's coffee export growth driver. The analysis using export decomposition showed that since 1994-2013, Indonesian coffee export has been dominated by commodity (grean bean). Export in the form of commodity is fragile regarding it's volatile price in the international market. This lead to recommend higher processed coffee incorporated in Indonesian coffee export structure. At the same time, regarding the characteristics of the product, the diversification of Indonesian coffee product from green bean to coffee extract is in parallel with the destination country. Gravity model on top three destination countries for Indonesian coffee extract, namely Phillipines, China and Lebanon suggest that supply side, trade agreement and currency are the most influencing factors to trade, and that distance plays insignificant role.
\end{abstract}

Keywords : Arabica, Coffee, Export, Robusta, Roast

\section{PENDAHULUAN}

Kopi merupakan salah satu tanaman perkebunan yang penting karena paling tidak dua hal. Yang pertama adalah dari sisi produksi. Tanaman ini merupakan penyokong perekonomian melalui basis produksi bahan mentah dan basis penyerapan tenaga kerja. Pada tahun 2012, produksi kopi Indonesia mencapai 8,8\% dari total produksi dunia atau menempatkan Indonesia sebagai produsen kopi terbesar ketiga secara global setelah Brazil dan Kolombia $^{1)}$. Luas areal tanaman kopi pada tahun 2013 adalah terbesar ketiga setelah sawit dan karet. Pada tahun 2010, areal perkebunan kopi rakyat diperkirakan mencapai 96,07\% dari total area penanaman kopi di Indonesia sedangkan produksi dari perkebunan rakyat mencapai $95,78 \%$ dari total produksi kopi, sedangkan produksi perkebunan negara dan swasta masing-masing hanya $2,05 \%$ dan $2,18 \%^{2)}$. Proporsi yang relatif sama juga diperkirakan terjadi di tahun 2011-2014. Hal ini menyebabkan perkebunan rakyat memainkan peranan vital dalam produksi kopi nasional. Di samping itu, karena area penanaman kopi tersebar di seluruh wilayah Indonesia yang bukan termasuk wilayah perkotaan, sektor kopi berperan penting bagi pembangunan pedesaan. Berdasarkan Keputusan Menteri Pertanian nomor 3399/Kpts/PD.310/10/2009 di-tentukan kopi bersama 14 komoditas lainnya sebagai komoditas strategis yang menjadi unggulan nasional agar diprioritaskan untuk difasilitasi dan dikembangkan.

Kedua, kopi juga memiliki peran di sisi perdagangan. Kopi merupakan hasil pertanian yang diperdagangkan secara luas dan menjadi komoditas yang paling penting setelah minyak bumi. Saat ini, Indonesia merupakan salah satu 
pemasok kopi penting di dunia setelah Brazil, Vietnam dan Kolombia. Proporsi produk kopi Indonesia yang diekspor mencapai $67 \%$ dari total produksi dan sisanya untuk konsumsi domestik. Ekspor kopi ditunjang oleh suplai yang besar proporsinya. Di sisi lain, terdapat peluang dari tren impor kopi dunia yang berkembang dari US\$ 9,52 trilyun di tahun 2001 menjadi US\$ 36 trilyun di tahun 2013. Menyadari akan potensi ekspor kopi, Kementerian Perdagangan meng-kategorikan kopi sebagai salah satu dari sepuluh produk prospektif ekspor yang terus didorong ekspornya agar terus bisa menyokong performa ekspor Indonesia secara keseluruhan.

Dilihat dari kinerja secara keseluruhan, ekspor kopi Indonesia berfluktuasi baik dari nilai dan volume (Gambar 1). Pertumbuhan kumulatif ekspor kopi selama 20 tahun (tahun 1994-2013) mencapai 111\%, atau sebesar US\$ 1,47 Miliar di tahun 2013 $(0,98 \%$ dari total ekspor non-migas Indonesia). Secara nilai, ekspor kopi meningkat rata-rata $5,61 \%$ per tahun selama periode 1994-2013, namun dalam perkembangannya beberapa kali mengalami perubahan tren.

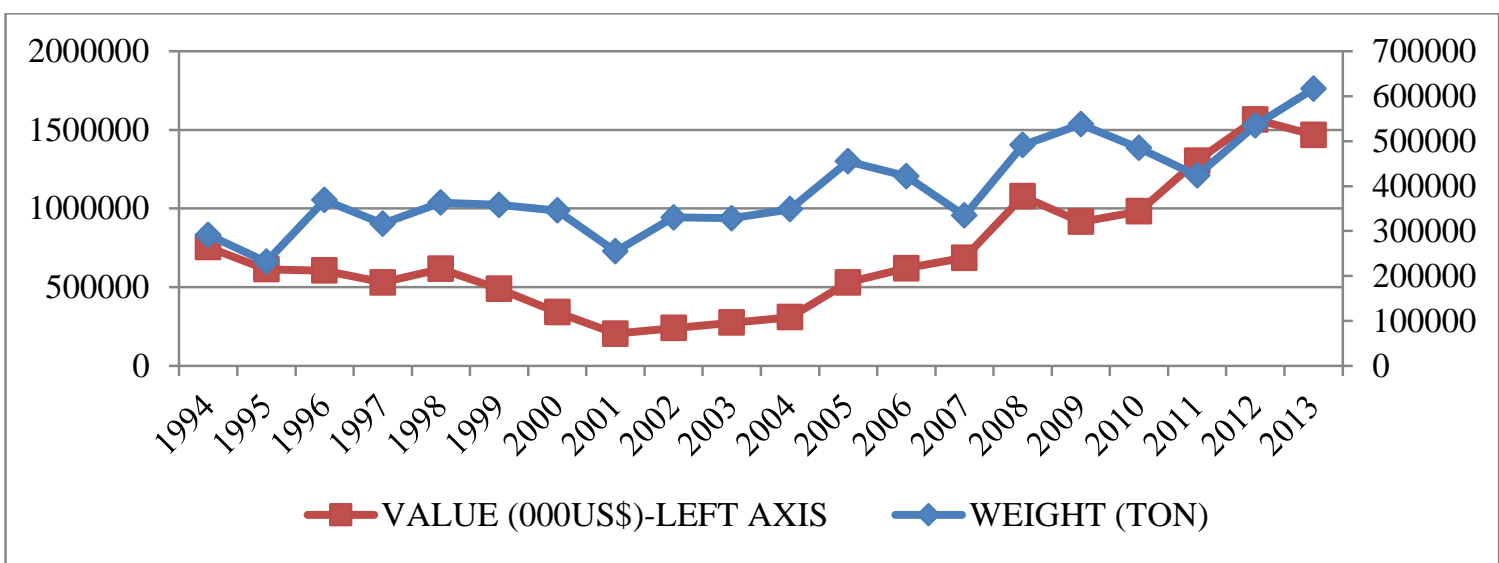

Sumber : BPS, 2014 (diolah)

Gambar 1 Perkembangan Ekspor Kopi Indonesia Periode 1994-2013

Selama periode 1994-1998 nilai ekspor kopi berkisar antara US\$ 753,63 juta - US\$ 529,67 juta dengan kecenderungan penurunan $5,37 \%$ per tahun. Ini merupakan integrasi terhadap kondisi global akibat diberlakukannya liberalisasi pasar untuk produk kopi di tahun 1990 sehingga mengakibatkan ketidakstabilan dari segi harga. Pada awal masa liberalisasi, yaitu pada periode pertengahan tahun 1989 hingga tahun 1993 terjadi keterpurukan harga kopi secara internasional dan mulai naik kembali pada tahun 1994.

Setelah menurun di periode 1994-1998, ekspor kembali turun ke nilai terendah di tahun 1999-2004. Ini merupakan periode dimana nilai ekspor kopi Indonesia mencapai nilai terendahnya sepanjang periode pengamatan. Hal ini merupakan integrasi dari coffee crisis/krisis kopi (keterpurukan harga komoditas kopi) yang imbasnya menimpa negara-negara produsen. Dengan titik terendah di tahun 2001, sebesar US\$203,54 juta, tahun 2002 nilai ekspor mulai naik pelan mencapai US\$ 309,11 juta di tahun 2004. Pasca tahun 2004, nilai ekspor kembali naik seiring dengan kenaikan harga internasional kopi, hingga pada tahun 2008, ekspor kopi menembus angka US\$ 1,08 milyar. Setelah turun kembali di tahun 2009-2010, pada tahun 2010-2013 nilai ekspor kembali di atas US\$ 1 milyar. Alasan yang sama adalah 
harga internasional yang meningkat dan mencapai puncaknya di pertengahan tahun 2011.

Pertumbuhan ekspor dari sisi nilai lebih tinggi dari pertumbuhan dari sisi volume yang tumbuh dengan rata-rata $3,57 \%$ per tahun selama periode 1994-2013. Volume ekspor berfluktuasi tiap satu hingga tiga tahun. Titik-titik terendah volume ekspor kopi antara lain di tahun 1995, 1997, 2001, 2007, dan 2011. Volume terendah tersebut juga direspon dengan nilai ekspor yang rendah, terkecuali di tahun 2011, di mana saat volume rendah, nilai ekspor justru menanjak naik.

Fluktasi yang tinggi pada nilai ekspor kopi selain disebabkan oleh hal teknis dan volume ekspor, juga disebabkan karena terlalu bergantungnya ekspor kopi Indonesia terhadap komoditas (biji kopi). Komoditas kopi harganya ditentukan secara internasional dan sangat berfluktuasi sehingga hal ini mempengaruhi kinerja ekspor kopi Indonesia secara keseluruhan.

Selain kebergantungan ekspor kopi Indonesia terhadap komoditas, negara tujuan ekspor juga terkonsentrasi. Pada tahun 1994, ekspor biji kopi Indonesia ditujukan ke 39 negara tujuan ekspor, dengan 26 negara di antaranya adalah negara industri maju di kawasan Amerika dan Eropa yang mencapai 68\% dari total ekspor biji. Ekspor ke sepuluh negara tujuan utama menguasai $91,19 \%$ dari total ekspor biji kopi Indonesia. Pada tahun 2003, ekspor ditujukan ke 79 negara dengan komposisi negara maju menguasi sekitar $84 \%$ dari dari total ekspor biji. Ekspor ke sepuluh negara tujuan utama menguasai $76,76 \%$ dari total ekspor biji kopi Indonesia. Namun demikian, pada tahun 2013, konsentrasi ekspor kopi biji ke negara maju di kawasan Amerika, Eropa dan Jepang berkurang mencapai sekitar $63 \%$ dengan ekspor ke sepuluh negara tujuan utama mencapai $69,69 \%$. Jumlah negara tujuan ekspor berkurang menjadi hanya 63 negara.

Kebergantungan ekspor terhadap komoditas dan negara tertentu berimbas pada berfluktuasinya ekspor kopi dan kinerja ekspor kopi. Berdasarkan Teori Kebergantungan (dependency theory) kebergantungan permanen yang terjadi di negara berkembang terhadap negara maju adalah karena kepentingan negara-negara metropolis tersebut sebagai pusat kapitalis dunia.

Salah satu poin pemikiran dari teori ini adalah negara pinggiran dapat berkembang dan mampu mengembangkan industrinya secara mandiri bila memiliki sedikit keterkaitan dengan negara kapitalis. Hal ini karena munculnya kawasan yang terbelakang adalah karena kawasan tersebut merupakan penghasil ekspor barang mentah primer yang tidak memperoleh keuntungan yang seharusnya melalui perdagangan internasional. Hubungan ini menjadi sangat timpang, karena negara kapitalis maju justru semakin meningkatkan industri, teknologi dan akumulasi modalnya. Teori kebergantungan ini, walaupun menjelaskan ekonomi secara keseluruhan, juga melibatkan sisi ekspor. Ketergantungan ekspor pada negara maju dapat menyebabkan kebergantungan pada ekspor bahan mentah/komoditas.

Dari sisi produk, terms of trade kopi sebagai komoditas terus menurun terhadap harga produk kopi olahan dan dengan demikian merugikan bagi pendapatan ekspor negara penghasil, terutama bila sangat bergantung pada ekspor komoditas kopi. Dalam jangka panjang, resiko yang tinggi di on-farm, bergejolaknya harga dan terms of trade yang terus menurun akan menyebabkan insentif bagi suplai komoditas kopi 
semakin menurun. Ini akan mengancam produksi yang berkelanjutan (sustainable production) dan selanjutnya ke sisi perdagangan dan ekspor.

Secara global, permasalahan ini sudah terwujud melalui terjadinya coffee crisis/krisis kopi. Cukup banyak literatur membahas tentang imbas krisis kopi, terutama di negara Afrika yang mengalami ketergantungan tinggi terhadap ekspor komoditas kopi, antara lain penelitian-penelitian dari Oxfam International. Istilah krisis kopi mengacu pada anjloknya harga kopi sebagai komoditas di pasaran internasional semenjak terjadinya liberalisasi pasar untuk produk kopi dan kemudian anjloknya harga ini berdampak secara luas pada kehidupan sosial ekonomi petani kopi, sebagai penanggung resiko terbesar. Namun demikian, imbasnya terhadap pelaku usaha kopi di Indonesia tidak terlalu ramai dibahas.

Salah satu penelitian mengenai dampak sosial ekonomi terjadinya krisis kopi terhadap petani kopi di Indonesia antara lain Gunadi (2007). Lokasi yang diteliti adalah Pasemah, salah satu daerah penghasil yang membentang di tiga provinsi yaitu Sumatera Selatan, Lampung dan Bengkulu. Hasil dari penelitian ini adalah meskipun petani kopi Indonesia sempat mengalami masa kejayaan hingga tahun 1980an, krisis kopi yang terjadi pada masa liberalisasi pasar menimbulkan dampak yang cukup serius bagi petani kopi di Pasemah. Untuk bertahan hidup petani mengubah pola konsumsi mereka. Beberapa mencari pekerjaan informal lainnya dan bahkan berurbanisasi ke Jabodetabek. Petani yang bertahan tetap mengusahakan kopi namun ada juga yang mendiversifikasikan jenis tanamannya.

Penelitian lainnya mengenai kopi antara lain Hutabarat (2010) yang melaksanakan penelitian dengan menggunakan teknik wawancara dan diskusi dengan para pemangku kepentingan di bidang kopi antara lain petani kopi, pedagang, pengusaha dan mengumpulkan data sekunder dari berbagai sumber. Hasilnya menunjukkan bahwa pajak nasional, kebijakan pemasaran dan krisis kopi yang terjadi secara internasional telah menghambat pertumbuhan industri kopi nasional.

Beberapa penelitian lainnya antara lain memberikan saran bahwa untuk meningkatkan kinerja ekspor kopi di Indonesia diperlukan langkah diversifikasi ekspor.

Penelitian terkini mengemukakan bahwa diversifikasi penting bagi negara berkembang. Perdagangan terbuka dapat mengurangi volatilitas saat suatu ekonomi negara terdiversifikasi dengan baik. negara berkembang umumnya terkonsentrasi untuk mengekspor kelompok produk yang sama kepada pasar yang terbatas. Kenyataan ini menyebabkan ketergantungan terhadap produk dan pasar tersebut.sangat tinggi. Bila terjadi goncangan dalam supply dan faktor eksternal lainnya maka akan mempengaruhi terms of trade negara yang bersangkutan dan mengguncang perekonomiannya. Di sisi lain, diversifikasi ekspor baik produk dan pasar membantu untuk menghasilkan pendapatan ekspor yang stabil dan mengurangi resiko ekonomi dan politik.

Hubungan diversifikasi ekspor terhadap pertumbuhan ekonomi juga banyak diteliti dalam penelitian lainnya, salah satunya Amiti dan Freund (2007) yang menghasilkan kesimpulan bahwa diversifikasi ekspor penting terutama untuk negara berkembang dan dengan itu dapat memicu peningkatan pertumbuhan ekonomi.

Kinerja ekspor dapat dinilai dari laju pertumbuhan baik dari sisi nilai 
maupun volume. Namun selain laju pertumbuhan ekspor, sisi yang perlu diperhatikan adalah tingkat diversifikasinya, baik produk maupun negara tujuan ekspor. Pengembangan ekspor yang berhasil adalah jika laju pertumbuhan ekspor tinggi dan komposisinya tidak didominasi negara tertentu dan produk tertentu.

Perusahaan dengan produktivitas yang tinggi dapat menghasilkan keuntungan tinggi hingga bisa menutupi biaya tetap yang besar jumlahnya untuk aktivitas ekspor. seiring dengan semakin terbukanya perdagangan, maka proteksi akan berkurang, sehingga akan mendorong perusahaan yang kurang produktif untuk keluar dari pasar. Dengan demikian, perusahaan dengan produktifitas yang tinggi yang akan bertahan. Untuk diversifikasi, bahkan dibutuhkan upaya yang lebih besar lagi.

Untuk mendiversifikasi ekspornya, pengusaha harus menghadapi resiko dan biaya awal yang lebih besar. Produk diversifikasi haruslah memiliki daya saing, diantaranya kualitas yang sesuai dan harga. Saat diversifikasi menunjukkan hasil, hal tersebut akan menstimulasi pengusaha lain untuk memasuki pasar ekspor. Dengan demikian pencetus diversifikasi bisa jadi memberikan keuntungan bagi pengusaha lainnya yang secara agregat baik untuk pertumbuhan. Namun, apabila gagal, kerugian yang dikeluarkan hanya ditanggung oleh pengusaha tersebut sendiri. Ini juga bisa berlaku untuk negara tujuan baru.

Berdasarkan hal ini, langkah diversifikasi memiliki disinsentif yang resikonya besar untuk individu pengusaha.

Dengan demikian, langkah diversifikasi menjadi kebijakan yang strategis untuk dilakukan secara nasional dibanding di tingkat perusahaan perusahaan atau daerah semata. Ini juga suatu langkah untuk membangun national interetest. Untuk itu, permasalahan yang dikaji dalam penelitian ini adalah bagaimana bentuk diversifikasi ekspor di bidang kopi di Indonesia dan faktor-faktor apa yang mempengaruhinya. Hal tersebut dapat menjadi dasar untuk menentukan saran kebijakan yang dapat dilakukan untuk meningkatkan kinerja ekspor kopi Indonesia.

Pengorganisasian tulisan ini adalah sebagai berikut : (1) bagian kedua pada penelitian ini membahas mengenai metode penelitian. (2) pemaparan mengenai hasil dan pembahasan pada bagian ketiga dan bagian terakhir adalah simpulan dan saran serta daftar pustaka.

\section{METODE PENELITIAN}

Data yang digunakan dalam model penelitian ini berupa data kuantitatif dan kualitatif. Data kuantitatif yang digunakan adalah data ekspor Indonesia untuk produk kopi dalam kategori HS sembilan dan sepuluh digit per negara selama periode 1994-2013 dan data konversi HS berupa tabel korelasi HS sembilan digit ke sepuluh digit (BTBMI 2007 dan BTKI 2012). Selain itu, data lainnya untuk analisis determinan diversifikasi ekspor antara lain mengikuti gravity equation, yaitu : PDB Indonesia, PDB negara tujuan baik total dan per kapita, populasi negara tujuan, jarak ekonomis, tarif/perjanjian perdagangan (FTA) dan nilai tukar. Data PDB diperoleh dari WDI (World Development Indicator) Worldbank, jarak diperoleh dari website CEPII, data mengenai FTA diperoleh dari WTO dan website ASEAN dan nilai tukar diperoleh dari Worldbank. Idealnya, data ekspor yang digunakan untuk mengukur level diversifikasi adalah data di tingkat perusahaan. 
Namun demikian, data mikro demikian tidak tersedia dan sangat sulit untuk memperolehnya melalui teknik pengambilan data primer. Dengan demikian, data yang akan digunakan adalah data sekunder dari Badan Pusat Statistik (BPS). Selain itu data kualitatif yang dibutuhkan berupa data yang berkaitan dengan perdagangan kopi dan umumnya diperoleh dari ICO (International Coffee Organisation) dan AEKI (Asosiasi Eksportir Kopi Indonesia).

Tahap awal analisis adalah pendefinisian produk kopi dalam kegiatan ekspor. Produk kopi dan turunannya yang tercatat dalam neraca ekspor dijelaskan kedalam ketiga kelompok produk yang menjelaskan sifat industrinya yaitu kopi biji (green bean), kopi sangrai (roasted coffee) dan kopi ekstrak (extract coffee) melalui pohon industri yang disesuaikan dengan pencatatan ekspor melalui sistem HS (Harmonized System) dan SITC (Standard International Trade Classification). Adapun pengelompokkan produk kopi ditampilkan pada Tabel 1.

Analisis struktur ekspor dilakukan melalui dekomposisi ekspor. Hal ini ditujukan untuk menganalisis struktur ekspor baik produk maupun negara tujuan ke dalam marjin ekspor yang membagi pertumbuhan ekspor menjadi tiga kategori yaitu : (1) marjin intensif, pertumbuhan nilai dari produk lama dan negara lama yang menggambarkan konsentrasi; (2) marjin ekstensif atau pertumbuhan ekspor yang berasal dari produk baru dan atau negara baru yang mencerminkan diversifikasi; (3) marjin yang hilang, baik dari produk yang tidak bertahan maupun negara tujuan yang tidak lagi menjadi tujuan ekspor. Dengan : $\Delta \mathrm{X}=$ pertumbuhan ekspor; $\mathrm{k}=$ produk yang diekspor; $\mathrm{K}_{0}$ dan $\mathrm{K}_{1}=$ produk yang diekspor pada tahun 0 dan tahun 1, dekomposisinya dapat dituliskan sebagai berikut :

$$
\Delta X=\sum_{K_{0} \cap K_{1}} \Delta X+\sum_{K_{1} / K_{0}} X_{k}-\sum_{K_{0} / K_{1}} X_{k}
$$

Terdapat perbedaan untuk menentukan kategori produk lama (PL) dan produk baru (PB) serta destinasi lama (DL) dan destinasi baru (DB). Dengan periode penelitian 1990-2005, Amurgo-Pacheco dan Pierola (2008) menentukan PL sebagai produk yang diekspor setidaknya tiga tahun sebelum tahun 1995 dan PB adalah produk yang diekspor paling tidak lima kali setelah tahun 1995. Sedangkan Tsivadze (2011) dengan periode penelitian tahun 1996-2008, mengkategorikan PL adalah produk yang diekspor dua kali dalam tiga tahun terakhir, dan PB sebagai produk yang diekspor sekali dalam tiga tahun terakhir dan paling tidak dua kali dalam tiga tahun berikutnya. Hal tersebut juga berlaku untuk penentuan DL dan DB.

Penelitian ini menggunakan periode data 20 tahun. Tahun 2003 dijadikan tahun patokan sehingga membagi data menjadi dua bagian. PL didefinisikan sebagai produk yang muncul paling tidak lima kali sebelum tahun 2003 dan PB paling tidak muncul maksimal tiga kali sebelum tahun 2003 dan lima kali setelah tahun 2003, baik berkesinambungan atau tidak. Hal ini mempertimbangkan siklus produk baru dan secara implisit penetrasi pasar ekspor dalam periode yang diamati. Sepuluh tahun atau lebih dipertimbangkan sebagai periode yang cukup relevan bagi pengembangan produk ekspor dan produk baru bertahan di pasar ekspor rata-rata selama dua tahun. Hal ini juga dilakukan untuk kategori DL dan DB.

Analisis ekonometrika dengan regresi data panel gravity digunakan untuk menganalisis faktor-faktor yang mempengaruhi arus diversifikasi ekspor 
kopi antara Indonesia dengan negara tujuan ekspor. Dalam model gravity sederhana, perdagangan antara negara $\mathrm{i}$ dan negara $j$ bersifat proporsional terhadap ukuran ekonomi dan berbanding terbalik dengan jarak, yang menjadi proksi bagi biaya transportasi diantara kedua negara. Secara umum dapat digambarkan seperti berikut:

$$
X_{i j}=A \frac{Y_{i} Y_{j}}{D_{i j}}
$$

Dimana $X_{\mathrm{ij}}$ adalah arus perdagangan ekspor antara negara i dan negara $j . Y_{i}$ adalah GDP untuk negara $i$ dan $Y_{j}$ untuk negara $\mathrm{j}$. $\mathrm{D}_{\mathrm{ij}}$ sebagai jarak geografis antara kedua negara. Di model gravity ini, variabel dependen dikelompokkan dalam tiga variabel, yaitu :

1. Variabel-variabel yang mewakili total permintaan potensial negara pengimpor yang terdiri dari PDB negara tujuan baik total dan per kapita, dan jumlah penduduk negara tujuan.

2. Variabel-variabel indikator total penawaran potensial negara pengekspor yang terdiri dari PDB Indonesia per kapita.

3. Variabel-variabel pendukung atau penghambat aliran perdagangan antara negara pengimpor dan negara pengekspor yang terdiri dari jarak ekonomi, perjanjian perdagangan/ tarif dan nilai tukar.

Model gravity yang diperluas tersebut dituliskan sebagai berikut :

$\ln \mathrm{X}_{\mathrm{ijt}}=\alpha+\beta \ln Y_{i t}+\gamma \ln Y_{j t}-\delta \ln \mathrm{D}_{i j}+\lambda T_{j t}+$ $\varepsilon_{i j t}$

Dimana $X_{\mathrm{ijt}}$ adalah ekspor antara negara i dan $\mathrm{j}$ pada periode tertentu; $Y_{i t}$ adalah GDP untuk negara i; $Y_{j t}$ adalah GDP untuk negara $\mathrm{j}$; $\mathrm{D}_{i j}$ adalah jarak geografis antara negara $\mathrm{i}$ dan $\mathrm{j}$; dan $T_{j t}$ adalah Trade Policy Index (dapat berupa kebijakan perdagangan).
Adapun model yang digunakan dalam penelitian ini adalah:

$$
\begin{aligned}
\log \left(X_{\text {dit }}\right)= & \alpha+\beta_{1} \log \left(\text { GDPP_d } d_{t}\right)+\beta_{2} \\
& \log \left(\text { GDP_i } i_{t}\right)+\beta_{3} \log (\text { cur })+ \\
& \beta_{4} \log (\text { ECODIS_di })+\beta_{5} \\
& \text { AGREE }+\varepsilon_{\text {ijt }}
\end{aligned}
$$

Dengan :

$\mathrm{X}_{\mathrm{dit}} \quad=$ nilai ekspor pada marjin ekstensif dari Indonesia ke Negara tujuan-d, untuk produk i dalam kategori HS 10 digit di tahun-t

GDPP_d $\mathrm{d}_{\mathrm{t}}=$ GDP Per kapita Negara tujuan di tahun-t
GDP_ $\mathrm{i}_{\mathrm{t}}=$ GDP Indonesia $\mathrm{di}$ tahun-t

ECODIS_d = jarak ekonomi antara Indonesia dan Negara tujuan-d dengan rumus matematis sebagai berikut :

$$
E_{C O D I S_{d i}}=\frac{D I S_{-d}}{G P_{d} / \sum_{\text {kawasan }}}
$$

dengan :

$\begin{aligned} \begin{array}{l}\sum_{\text {pasar }} G D P_{\text {kawasan }}= \\ \text { DIS d }=\end{array} & \text { jarak ibu kotan GDP kawasan } \\ & \text { Indonesia dengan ibu kota } \\ & \text { negara d }(\mathrm{km}) \\ \text { GDPd }= & \text { tingkat perekonomian } \\ & \text { negara d (US } \$ \text { ) } \\ \text { AGREE = } & \text { dummy perdagangan bebas } \\ & \text { yang bernilai 1 bila } \\ & \text { Indonesia menjalani } \\ & \text { perjanjian perdagangan } \\ & \text { dengan Negara tujuan-d } \\ & \text { Sebagai proxy untuk tarif } \\ & \text { dan hambatan perdagangan } \\ & \text { lainnya) (negara } \\ = & \text { Indonesia } \\ \text { pengekspor) } & \text { Negara tujuan diversifikasi } \\ \mathrm{i}= & \text { ekspor produk kopi } \\ \mathrm{j}= & \text { Konstanta / intersep } \\ \alpha \quad & \text { Error term }\end{aligned}$




$$
\begin{aligned}
& \beta_{1}, \beta_{2}, \beta_{3}, \beta_{4}, \beta_{5}=\text { Parameter } \quad \text { yang } \quad \mathrm{H}_{0}: \text { Homoskedastisitas } \\
& \text { diestimasi } \quad \mathrm{H}_{1} \text { : Heteroskedastisitas }
\end{aligned}
$$

Dalam gravity model dari perdagangan bilateral, diperlukan pengujian asumsi pada data panel untuk mengetahui estimasi bias. Jika model yang terpilih berdasarkan uji Hausman adalah Random Effect Model (REM) maka estimasi dari model diasumsikan best linier unbiased estimator (BLUE) dan tidak perlu dilakukan pengujian terhadap tiga asumsi utama model BLUE (non-multicolinierity, homoskedasticity, dan nonauto-corelation). Hal ini dikarenakan dua alasan, yaitu: (i) sifat data panel adalah bebas dari gejala multikolinieritas; dan (ii) REM adalah model generalized least square (GLS), dan estimasi dengan menggunakan GLS secara otomatis sudah terbebas dari gejala autokorelasi, bahkan terbebas dari gejala heteroskedastisitas yang disebabkan variansi sisaannya konstan (Gujarati, 2004).

Jika model yang terpilih adalah Fixed Effect Model (FEM) maka perlu dilakukan pengujian terhadap asumsi sisaan, sebagai berikut:

\section{a. Uji Heteroskedastisitas}

Asumsi pertama yang harus dipenuhi dalam persamaan regresi adalah bahwa taksiran parameter dalam model regresi bersifat BLUE maka varian $\left(\mathrm{u}_{\mathrm{i}}\right)$ harus sama dengan $\sigma^{2}$ (konstan), atau semua residual atau error memiliki varian yang sama. Kondisi itu disebut dengan homos-kedastisitas. Apabila varian tidak konstan atau berubah-ubah disebut dengan heteroskedastisitas. Untuk mendeteksi adanya heteroskedastisitas dapat meng-gunakan metode Breusch-Pagan Test. Jika nilai probabilitas (Prob>chi2) lebih besar dari $\alpha$ (0.05) maka dapat disimpulkan bahwa tidak terjadi heteroskedastisitas. Hipotesis dari uji heteroskedastisitas:
Hipotesis nol akan ditolak bila (Prob $>$ chi2 $)<\alpha$ atau nilai chi2 $>$ nilai kritis t-tabel.

\section{b. Uji Autokorelasi}

Autokorelasi adalah korelasi yang terjadi antar observasi dalam satu peubah atau korelasi antara error masa yang lalu dengan error pada saat ini. Uji autokorelasi yang dilakukan tergantung pada jenis data dan sifat model yang digunakan. Autokorelasi dapat memengaruhi efisiensi dari penduganya. Untuk melakukan uji autokorelasi pada data panel dapat menggunakan Wooldridge test. Jika nilai probabilitas (Prob>F) lebih besar dari $\alpha(0.05)$ maka dapat disimpulkan bahwa tidak terjadi autokorelasi. Hipotesis dari uji autokorelasi:

$$
\begin{aligned}
& \mathrm{H}_{0} \text { : tidak ada autokorelasi } \\
& \mathrm{H}_{1} \text { : ada autokorelasi }
\end{aligned}
$$

Hipotesis nol ditolak bila $($ Prob $>F)<\alpha$.

Pengujian parameter model bertujuan untuk mengetahui kelayakan model dan apakah koefisien yang diestimasi telah sesuai dengan teori atau hipotesis. Pengujian parameter tersebut adalah sebagai berikut:

\section{a. Uji-F}

Uji-F digunakan untuk melakukan uji hipotesis koefisien (slope) regresi atau parameter model secara bersamaan. Kriteria pengujiannya adalah jika nilai nilai $\mathrm{F}$ observasi $>\mathrm{F}$ tabel atau nilai probabilitas $F$-statistic < taraf nyata $(\alpha)$, maka keputusan menolak $\mathrm{H}_{0}$ signifikan. Dengan menolak $\mathrm{H}_{0}$ berarti minimal ada satu peubah bebas yang berpengaruh nyata terhadap peubah tak bebas.

\section{b. Uji-t}

Setelah melakukan uji koefisien regresi secara keseluruhan, maka 
langkah selanjutnya adalah menguji koefisien regresi secara parsial menggunakan uji-t. Hipotesis pada uji-t adalah : $\mathrm{H}_{0}: \beta_{\mathrm{i}}=0$ Vs $\mathrm{H}_{1}: \beta_{\mathrm{i}} \neq 0$. Keputusan dalam pengujian ini dilakukan dengan membandingkan nilai t-hitung dengan t-tabel atau dengan melihat nilai probabilitas dari t-hitung. Jika nilai t-hitung $>$ t-tabel atau jika nilai probabilitas $\mathrm{t}<\alpha=0,05$ maka keputusan menolak $\mathrm{H}_{0}$ adalah signifikan. Kesimpulannya adalah peubah bebas secara parsial signifikan mempengaruhi peubah tak bebas.

\section{c. Koefisien Determinasi $\left(\mathbf{R}^{2}\right)$}

Koefisien determinasi (Goodness of Fit) merupakan suatu ukuran yang penting dalam regresi, karena dapat menginformasikan baik atau tidaknya model regresi hasil estimasi. Nilai $\mathrm{R}^{2}$ mencerminkan seberapa besar variasi dari peubah bebas $Y$ dapat diterangkan oleh peubah tak bebas $X$ dengan nilai berkisar antara 1-10. Semakin tinggi nilai koefisien determinasi maka model akan semakin baik.

Keputusan untuk memilih model yang digunakan dalam analisis data panel didasarkan pada uji Hausman. Uji Hausman dilakukan untuk memilih apakah model yang digunakan Fixed Effect atau Random Effect (Firdaus, 2011). Digunakan model Fixed Effect apabila statistik uji yang dihasilkan tolak $\mathrm{H}_{0}$ dan menggunakan Random Effect apabila tidak tolak $\mathrm{H}_{0}$.

\section{HASIL DAN PEMBAHASAN}

\section{Gambaran Umum Perdagangan Kopi}

Secara historis, perkembangan produk kopi di dunia dibedakan dalam dua periode. Periode pertama yaitu dari tahun 1963-1989 dimana suplai kopi diatur oleh suatu badan ICO (International Coffee Organization) melalui berbagai perjanjian internasional kopi (International Coffee Agreements) yang mewakili seluruh negara produsen, termasuk Indonesia, dan sebagian besar negara konsumen dengan tujuan mengatur suplai dan menjaga kestabilan harga. Bentuk intervensi tersebut antara lain adalah kuota yang ditetapkan di tiga periode, yaitu 1963-1972, 1980-1986 dan 1987-1989.

Pada akhir tahun 1989, kopi merupakan komoditas pertama yang diliberalisasi dan sistem kuota tidak lagi diberlakukan. Implikasinya harga untuk komoditas kopi dibentuk melalui mekanisme pasar. Dengan demikian, fluktuasi harga semakin tinggi dan semakin sering terjadi. Harga internasional kopi dapat dilihat pada Gambar 2.

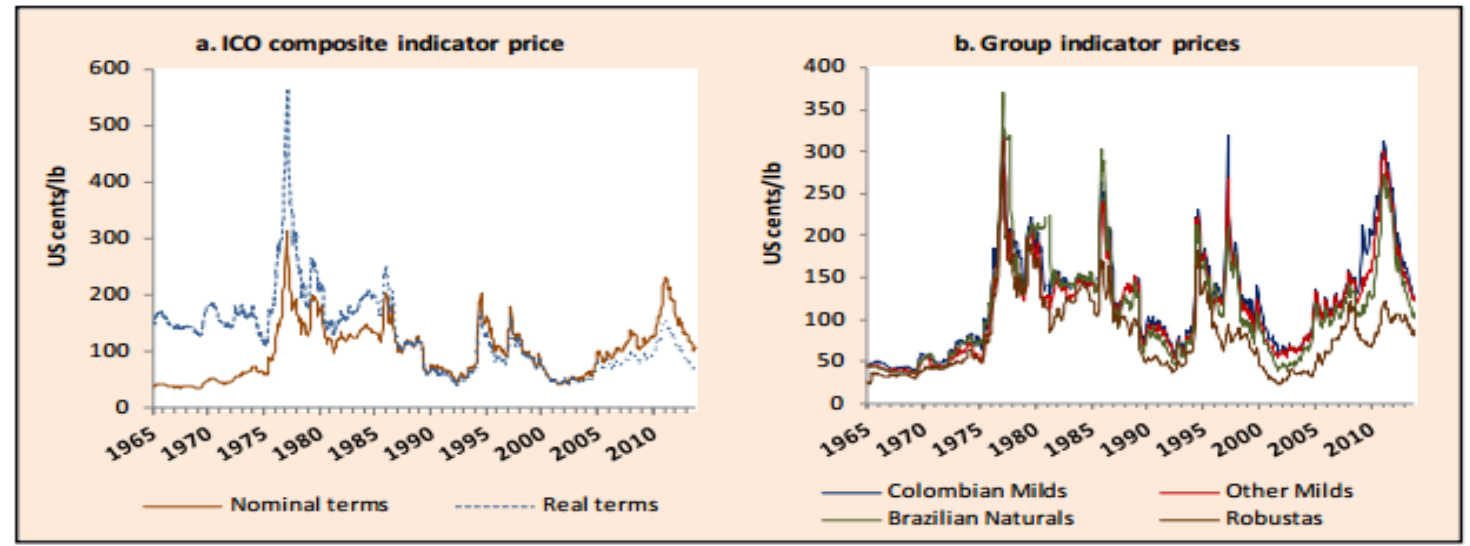

Sumber : ICO, 2015

Gambar 2 Harga internasional komposit biji kopi berdasarkan jenis 
Keterpurukan harga pertama terjadi segera setelah mekanisme pasar diberlakukan, yaitu selama periode 1989-1993. Melihat hal ini, di tahun 1993, negara produsen kopi berupaya untuk membentuk kartel bernama Association of Coffee Producing Countries (ACPC) untuk menjaga kestabilan harga. Indonesia turut bergabung ke dalamnya membuat asosiasi ini menguasai $85 \%$ produksi biji kopi global. Namun sayangnya upaya ini tidak berhasil karena tidak semua negara, terutama di Amerika Latin bergabung, sehingga menciptakan ketidakefisienan kebijakan yang ditetapkan organisasi ini.

Namun demikian, harga mulai menanjak kembali hingga terjadi keterpurukan yang lebih parah. Harga kopi mencapai level terendahnya semenjak periode mekanisme pasar pada tahun 1999-2004 setelah sebelumnya bangkit dari satu periode keterpurukan harga di tahun 1989-1993.

Keterpurukan harga (coffee crisis) di periode 1999-2004 paling tidak disebabkan oleh empat hal yaitu: (1) perubahan struktur menjadi keterbukaan pasar (tekanan harga akibat oversupply robusta), (2) kekuatan yang tidak seimbang di pasar antara industri hulu dan hilir, (3) teknologi baru yang menyebabkan kualitas kopi yang diperdagangkan secara umum menurun namun produksi meningkat (yang antara lain disebabkan masuknya Vietnam sebagai pemain baru dan Brazil yang berusaha meningkatkan eksistensinya), dan (4) tidak ada alternatif lain bagi pelaku usaha on-farm/ kegagalan pembangunan pedesaan (yang melibatkan petani kopi) ${ }^{8)}$. Imbas yang terjadi akibat krisis tersebut berbeda-beda di seluruh negara produsen. Salah satu faktor yang mempengaruhi adalah dari seberapa besarnya kebergantungan ekspor suatu negara produsen terhadap komoditas kopi.

Statistik harga internasional kopi mulai menunjukkan adanya kenaikan setelah tahun 2004, hingga mencapai puncaknya di tahun 2011. Mengacu pada prediksi International Coffee Organization (ICO), permintaan kopi naik dua hingga tiga persen setiap tahunnya. Namun, dengan kondisi tingginya curah hujan membuat banyak bunga kopi mengalami kerontokan hingga panen kopi di negara produsen pun berkurang. Dengan demikian, ekspor pun mengalami hambatan. Harga ekspor kopi pada 2011 naik diperkirakan karena produksi yang ketat ditengah permintaan yang stabil namun dengan tren meningkat.

Salah satu penyebab keterpurukan harga kopi adalah ketidakseimbangan kekuatan di pasar. Secara global ada sekitar 70 negara penghasil kopi. Produksi kopi di negara berkembang antara lain di kawasan Amerika Latin, Afrika dan Asia mencapai 90\% dari total produksi kopi dunia. Di sisi lain, konsumsi kopi didominasi oleh negara industri maju (terkecuali di Brazil, dimana konsumsi kopi juga besar) terutama Amerika dan Eropa. Dengan demikian, hubungan antara produsen dan konsumen terbagi menjadi dua blok yaitu Utara-Selatan (industri maju-negara berkembang). 
Semenjak terjadinya peralihan kepada mekanisme pasar, terjadi ketimpangan dalam kekuatan dalam pasar antara industri hulu dan hilir. Dalam hal ini, industri hulu diwakili oleh negara produsen dan industri hilir diwakili oleh negara konsumen. Secara global, kekuatan beralih kepada negara konsumen.

Ketidakseimbangan kekuatan di pasar ini dapat dilihat dari distribusi pendapatannya (Gambar 3). Sebelum diberlakukan liberalisasi pasar, negara produsen yang berjumlah sekitar 70 negara masih memperoleh sekitar 20\% dari total pendapatan sektor kopi, yang terdiri dari harga untuk petani dan nilai tambah di negara produsen. Sedangkan setengah dari pendapatan total sektor ini dinikmati konsumen. Namun demikian, proporsi ini terus menurun dengan harga yang diterima petani semakin rendah dan negara produsen semakin kehilangan kekuatan dalam meningkatkan nilai tambah produk kopi. Sementara di negara konsumen industri kopi justru terus berkembang.
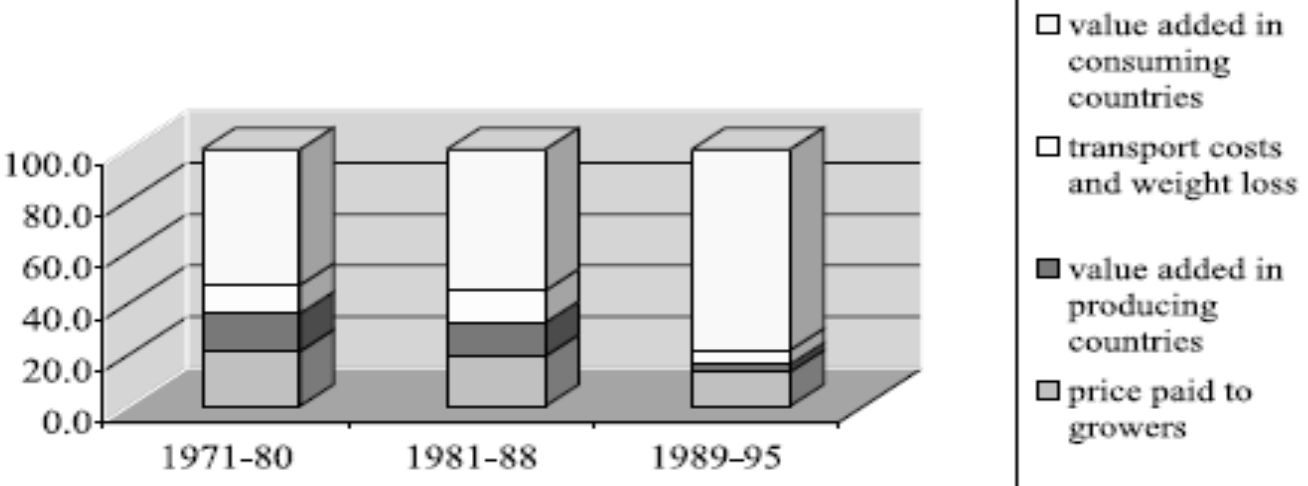

Sumber : Talbot (1997a) dalam Ponte (2002)

Gambar 3 Distribusi pendapatan kopi

Ketidakseimbangan ini juga dapat ditelusuri dari struktur mata rantai pemasaran kopi (Gambar 4). Secara global, kopi memiliki rantai yang cukup panjang sejak dipanen pelaku on-farm/petani hingga dapat dikonsumsi oleh konsumen. Sejak liberalisasi pasar kopi, peran negara sebagai marketing board dihapus dan ekspor dapat dilakukan oleh perusahaan secara pribadi. Umumnya eksportir mengekspor kopi dalam bentuk bahan mentah dan kemudian diperdagangkan secara internasional. Kopi kemudian diperdagangkan oleh international trader dan diolah di negara konsumen oleh roaster/pengolah dan dipasarkan melalui retail, supermarket, restoran dan kafe.

Setelah periode liberalisasi pasar, fluktuasi harga juga dipengaruhi oleh spekulasi pada pasar berjangka. Ini menyebabkan terjadinya tingkat konsentrasi yang semakin tinggi bagi pemain di pasar. International trader semakin terpusat pada beberapa perusahaan saja. Sebanyak enam perusahaan menguasai hampir $50 \%$ perdagangan kopi, antara lain Neumann dan Volcafe menguasai $29 \%$ 
perdagangan (Ponte, 2002). Di level pengolah, beberapa perusahaan internasional ternama (roaster) seperti Nestle, P\&G/Smucker, Kraft, Sara
Lee, Tchibo, dan Lavazza mendominasi hampir separuh pasar kopi dunia tahun 2009 (Wendelspiess, 2010).

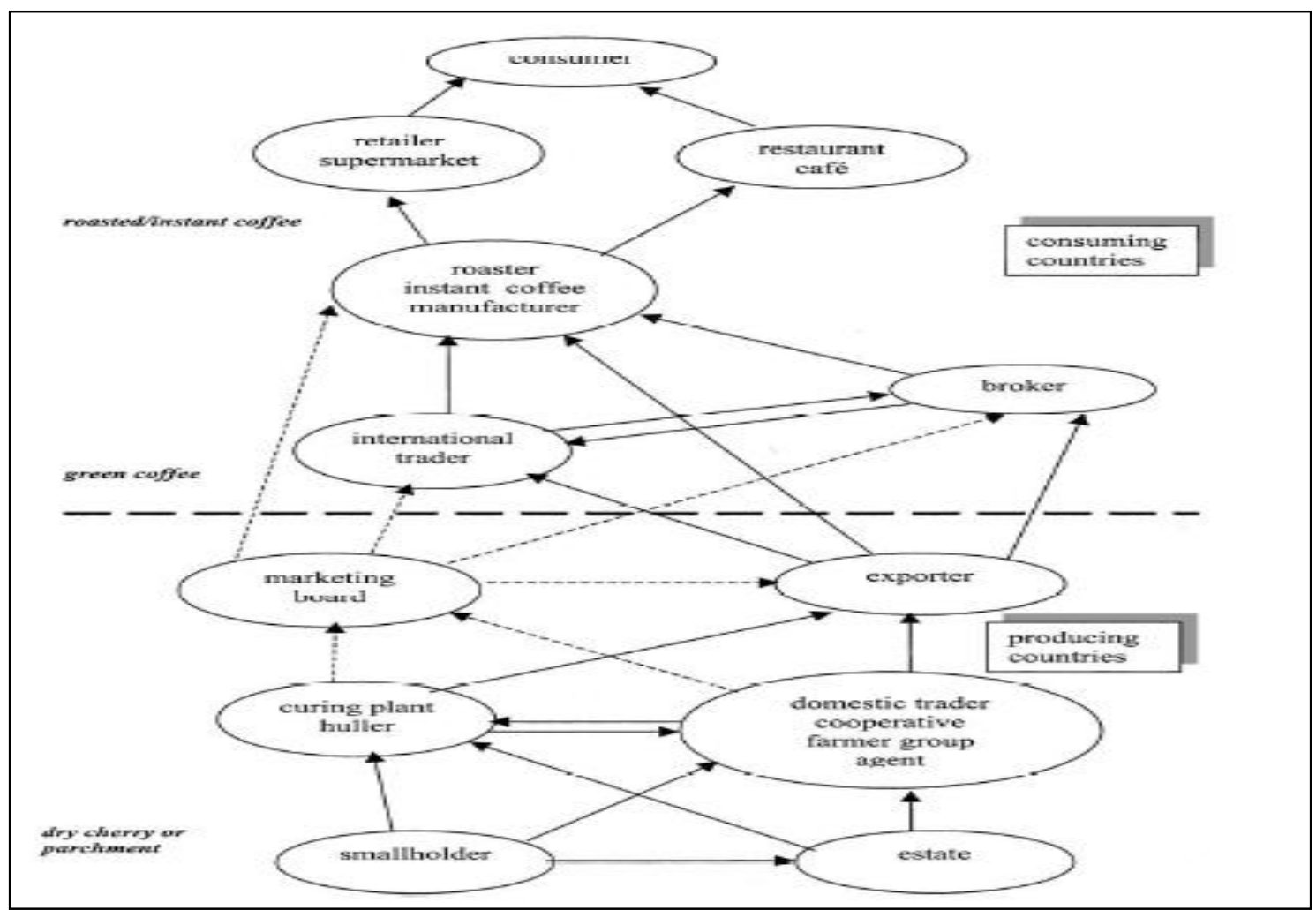

Sumber : Ponte, 2002

Keterangan : Garis putus-putus merupakan struktur yang ada sebelum liberalisasi pasar kopi

Gambar 4 Struktur umum rantai pemasaran kopi secara global

Industri kopi Indonesia sangat terintegrasi dengan kondisi global. Hal ini terutama karena tingginya proporsi kopi biji dalam ekspor kopi Indonesia. Konsentrasi yang tinggi terhadap ekspor komoditas mencapai $79-97 \%$ dari total nilai ekspor kopi. Konsentrasi bahkan lebih tinggi lagi di sisi volume, mencapai $81-98 \%$ dari total ekspor kopi (Gambar 5). Dengan demikian, ekspor kopi olahan hanya menyumbang sedikit peran terhadap perkembangan ekspor kopi
Indonesia. Sejak liberalisasi pasar, marketing board dihapus, sehingga perdagangan kopi dapat dilakukan oleh eksportir lokal. Dengan demikian, untuk menjaga kinerja ekspor kopi dan agar kopi Indonesia bisa bersaing dari segi harga, ditetapkan pajak ekspor nol persen untuk komoditas kopi yang diekspor. Ini turut mendukung ekspor kopi dilakukan dalam bentuk biji yang terus terjadi hingga saat ini. 


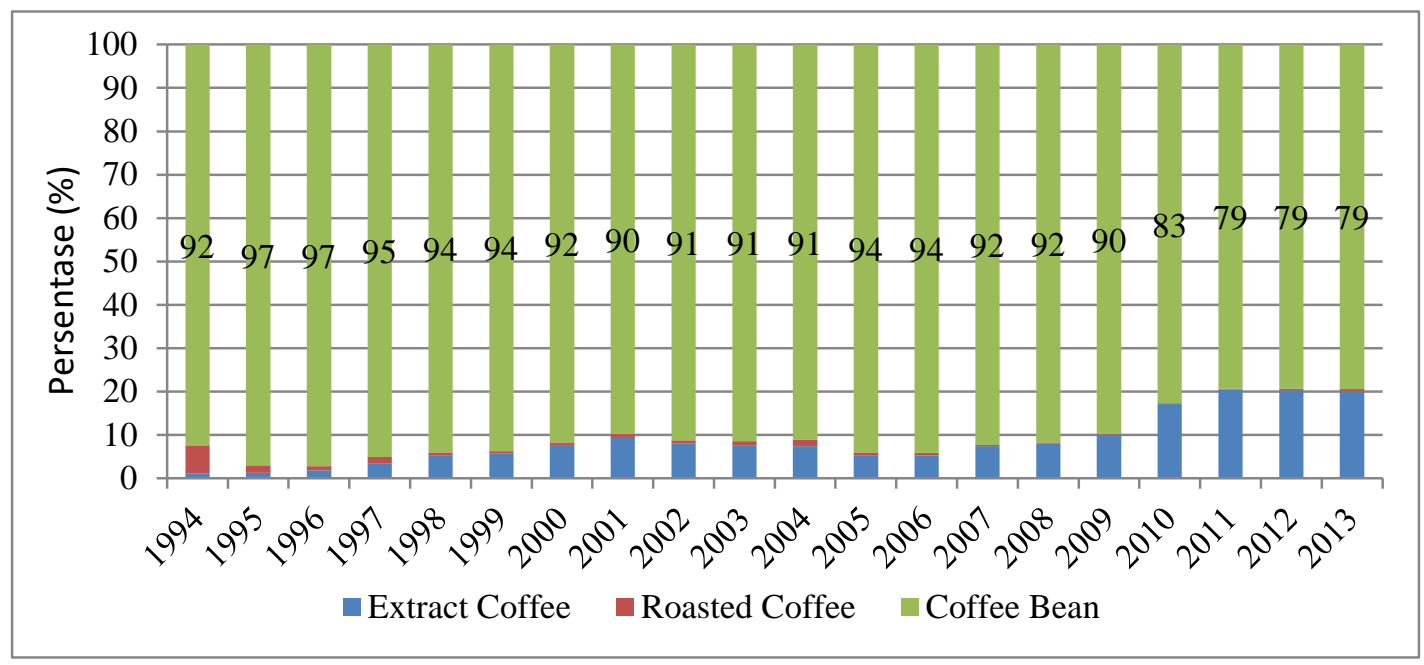

Sumber : BPS, 2014 (diolah)

Gambar 5 Komposisi ekspor kopi Indonesia berdasarkan kelompok produk, 1994-2013

Gambaran Umum Perdagangan Kopi Berdasarkan Jenis

Secara global, berdasarkan jenisnya, kopi yang dikonsumsi dan diperdagangkan secara komersial dibedakan menjadi dua jenis, yaitu arabika dan robusta. Konsumsi kopi dunia didominasi jenis arabika sekitar 70 persen dari total konsumsi dunia sedangkan $\quad 30 \%$ sisanya adalah konsumsi robusta.

Selera pasar ini tercermin juga dari produksi kopi dunia. Total produksi arabika di tahun panen 1989/1990 yang mencapai $72,5 \%$ dari total produksi dunia sedangkan $27,5 \%$ sisanya adalah jenis arabika. Namun demikian, proporsi ini menurun di tahun 2012/2013. Saat ini, produksi arabika diperkirakan mencapai $61,3 \%$ dari total produksi dunia sedangkan sisanya adalah produksi robusta (ICO, 2015).

Dari dua jenis tersebut, berdasarkan klasifikasi ICO, jenis kopi untuk komoditas dipisahkan kembali menjadi empat jenis (Gambar 1), yaitu Colombian milds, other milds, dan Brazilian natural dari jenis arabika dan robusta. Dari keempat jenis tersebut, Colombian milds yang memiliki harga tertinggi, disusul oleh other milds, Brazilian natural dan terakhir adalah robusta. Perbedaan harga biji kopi robusta dan arabika mencuat selama periode mekanisme pasar. Robusta sering dianggap sebagai kopi kelas dua atau kualitas rendah, karena rasanya yang agak getir, sehingga cenderung kurang disukai dibanding kopi jenis arabika.

Untuk kopi olahan, setidaknya terdapat dua jenis kelompok berdasarkan industrinya, yaitu kopi sangrai (roasted coffee) dan ekstrak kopi (extract coffee). Biji kopi arabika terutama digunakan sebagai bahan kopi sangrai sedangkan kopi robusta digunakan sebagai bahan dasar kopi ekstrak. Dengan meningkatnya teknologi, memungkinkan penggunaan kopi robusta dalam sangrai sebagai campuran. Karakteristik unik ini mempengaruhi tipe dan geografis konsumen untuk produk kopi. Kopi sangrai lebih disukai oleh konsumen yang sehari-hari memiliki budaya minum kopi hingga konsumsi per kapitanya juga tinggi. Negara-negara tersebut antara lain di kawasan Eropa, Amerika, Jepang, dan negara maju lainnya, terutama berada di belahan utara bumi. Sebaliknya, kopi ekstrak lebih digemari oleh konsumen di negara-negara yang lebih banyak minum 
teh, antara lain kawasan Asia-Pasifik, Russia dan Australia. (Gambar 6).

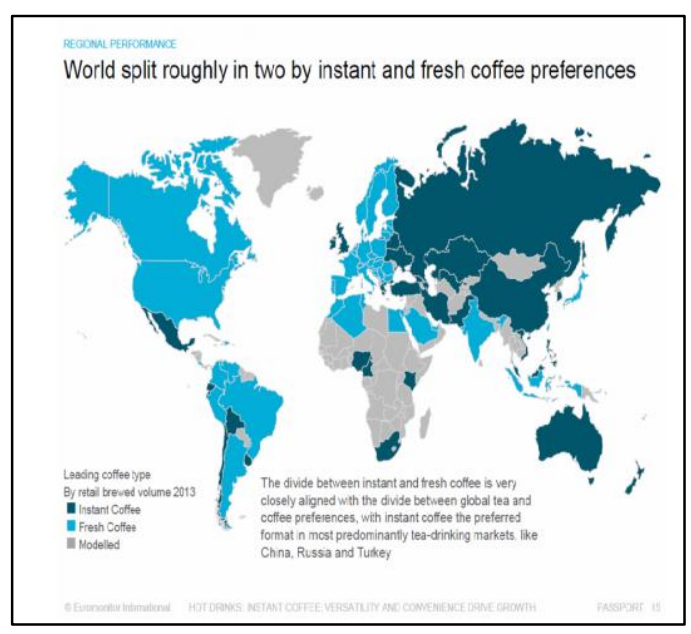

Sumber : Washington Post, 2015

Gambar 6 Geografi Konsumsi Kopi Dunia

Di Indonesia, ada dua jenis kopi yang diproduksi dan diperdagangkan secara komersil, yaitu robusta dan arabika. Walaupun produktivitas kopi arabika Indonesia lebih tinggi dari kopi robusta, produksi Indonesia saat ini didominasi oleh robusta, yaitu sekitar 79-97\% dari total produksi kopi di Indonesia selama periode 1999-2010 (AEKI, 2014). Produksi robusta pada tahun 2010 mencapai $86,51 \%$ dari total produksi kopi. Besarnya produksi jenis robusta dan kurang berkembangnya produksi arabika saat ini antara lain karena secara teknis ketinggian lahan yang cocok untuk penanaman arabika masih berupa hutan. Selain itu, pemeliharaan kopi robusta cenderung lebih mudah dan lebih kecil resikonya untuk terpapar penyakit dan hama.

Menurut AEKI, saat ini kopi arabika yang diekspor Indonesia adalah arabika mutu 1 berdasarkan sistem cacat kopi dengan SNI nomor 01-2907-2008 yang mengikuti perkembangan pasar global, persyaratan internasional dan resolusi ICO No. 407 tentang coffee quality improvement program yang diluncurkan sejak tahun 2002. Namun demikian, untuk kopi jenis robusta masih didominasi mutu 4 (60\%), mutu 5 dan mutu $6(30 \%)$ dan hanya 10\% dalam bentuk mutu 1 atau mutu 2, dalam skala mutu tertinggi hingga terendah : 1-6. Dengan demikian, terdapat indikasi permasalahan pada kualitas biji kopi yang dihasilkan. Adapun pengelompokkan produk kopi dapat dilihat pada Tabel 1.

Tabel 1 Korelasi antara pohon industri kopi, HS dan SITC

\begin{tabular}{cccll}
\hline $\begin{array}{c}\mathrm{N} \\
\mathrm{o}\end{array}$ & SITC & HS & $\begin{array}{l}\text { Pohon } \\
\text { Industri }\end{array}$ & Deskripsi \\
\hline 1 & 071.1 & 090110 & Biji & Green \\
& & 090112 & Kopi & Bean \\
2 & 071.2 & 090190 & Kulit & \\
& & 090120 & Kopi & Roasted \\
& & 090121 & Sangrai, & \\
3 & 071.3 & 090190 & Kopi & \\
& & 210111 & Ekstrak & Extract \\
& & 210112 & & \\
\hline
\end{tabular}

Sumber : Intracen, 2015 (diolah)

Salah satu solusi terkait pengembangan ekspor biji kopi yang diberikan dari berbagai penelitian sebelumnya adalah meningkatkan produksi specialty coffee (kopi kualitas tinggi dan memiliki sifat rasa yang unik karena berasal dari daerah tertentu). Indonesia memang memiliki keunggulan kekuatan dengan menjadi satu-satunya negara produsen kopi yang memiliki kopi spesialti terbanyak di dunia. Beberapa nama kopi spesialti Indonesia yang telah dikenal di manca negara dan menjadi bagian dari menu origin di Cafe di kota-kota besar dunia diantaranya adalah Gayo Coffee, Mandheling Coffee, Java Coffee, dan Toraja Coffee. Sedangkan beberapa nama yang saat ini sudah mulai dikenal diantaranya adalah Bali Kintamani Coffee, Flores Coffee, Prianger Coffee, dan Papua Coffee (AEKI, 2015). 
Dari segi harga, kopi spesialti memang memiliki harga yang lebih tinggi. Permintaan akan kopi spesialti memang meningkat, namun untuk pemasaran Indonesia mengalami kebergantungan. Diperkirakan 60-80\% dari ekspor kopi jenis arabika Indonesia dijual ke pembeli tunggal yaitu Starbucks Coffee (Ottaway, 2007).

\section{a. Struktur dan Kinerja Ekspor Produk Kopi Olahan}

\section{Kopi Sangrai}

Proses menyangrai kopi mengubah biji kopi baik secara fisik maupun kimiawi. Proses inilah yang mengeluarkan rasa dan aroma dari kopi. Biji kopi dan kopi spesialti menjadi bahan baku kopi sangrai. Saat ini, varian ekspor kopi sangrai semakin bertambah seiring dengan semaraknya gerai kopi secara global.

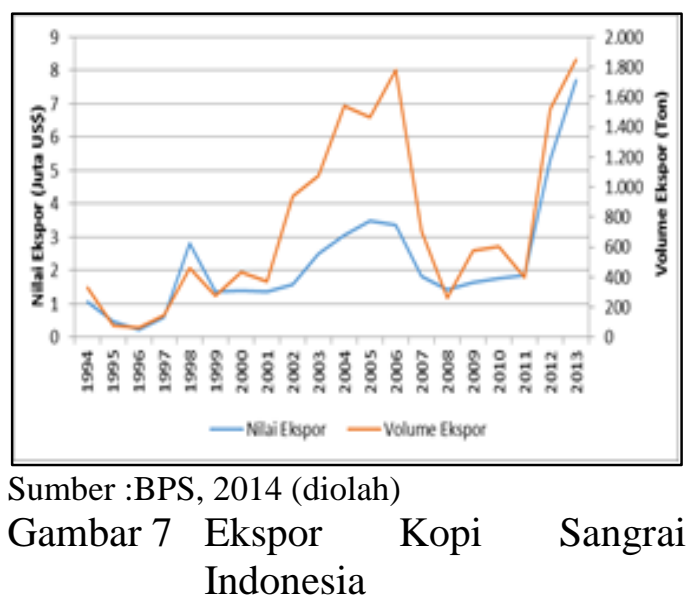

Di Indonesia, pangsa ekspor kopi sangrai sangat rendah. Pangsa ekspor kopi kelompok ini menguasai $0,15-6,52 \%$ dari total ekspor kopi Indonesia periode 1994-2013 (Gambar 7). Pada tahun 2013, pangsa ekspor kopi sangrai terhadap total ekspor kopi Indonesia hanya mencapai $0,53 \%$. Nilai ekspor dan volume cenderung fluktuatif, terutama periode 2001-2008, namun pada periode 2011-2013, baik volume dan nilai ekspor meningkat.

Pangsa ekspor yang rendah ini terutama disebabkan karakteristik kopi sangrai itu sendiri. Biji kopi sebagai bahan baku memiliki sifat yang lebih stabil dari kopi sangrai dan lebih tahan lama. Dengan demikian, proses menyangrai cenderung dilakukan di area/kawasan yang dekat dengan konsumen kopi sangrai, karena hemat waktu distribusi dan waktu simpan menjadi lebih lama. Umumnnya kopi sangrai dilakukan dalam skala besar oleh roaster.

Alasan teknis lainnya adalah karena produksi kopi arabika rendah proporsinya terhadap ekspor, padahal kopi arabika merupakan bahan baku kopi sangrai. Selain karena alasan teknis tersebut, alasan ekonomis mengapa ekspor kopi sangrai tidak dapat berkembang adalah karena tingginya konsentrasi persaingan di tingkat roaster. Kondisi monopolistik ini sulit untuk dipecahkan oleh Indonesia.

\section{Kopi Ekstrak}

Pangsa ekspor kopi olahan yang rendah dialami oleh Indonesia. Namun demikian, setelah tahun 2007, ekspor kopi ekstrak Indonesia mengalami perkembangan pesat. Saat ini Indonesia saat ini sedang mengembangkan industri ekstrak kopi secara bertahap, baik untuk domestik maupun ekspor. Berbeda dengan kopi sangrai yang berbahan dasar kopi jenis arabika, kopi ekstrak dan kopi espresso menggunakan bahan baku kopi jenis robusta. Dengan demikian, suplai bahan baku untuk pengolahan biji kopi menjadi kopi ekstrak cukup terjamin.

Perkembangan volume dan nilai ekspor kopi ekstrak memiliki korelasi yang sangat kuat (Gambar 8). Berbeda dengan ekspor biji kopi dan kopi sangrai yang bergejolak tinggi. Dengan demikian, kuantitas yang diekspor dapat 
merefleksikan nilai ekspor yang diperoleh hingga berkurang resiko dari pergerakan harga/unit value. Dilihat dari trennya, baik volume maupun nilai, ekspor kopi ekstrak mengalami peningkatan sejak tahun 1994-2013, walaupun terjadi sedikit penurunan di tahun 2012-2013.

Kopi ekstrak secara umum berbahan baku utama kopi jenis robusta dan berdasarkan selera yang dipisahkan secara geografis tidak digemari oleh konsumen di negara-negara Amerika dan Eropa yang paling banyak mengkonsumsi kopi (kecuali Eropa Selatan yang tidak terlalu pemilih).

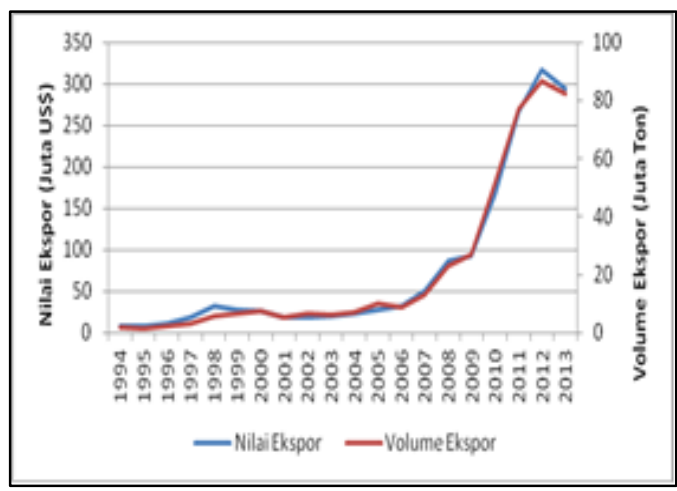

Sumber : BPS, 2014 (diolah)

Gambar 8 Ekspor Kopi Ekstrak Indonesia

\section{b. Dekomposisi Ekspor}

Proses dekomposisi ekspor membagi pertumbuhan ekspor ke dalam marjin intensif yang menandakan terjadinya konsentrasi, marjin ekstensif yang menandakan terjadinya diversifikasi dan marjin hilang yang berasal dari hilangnya negara atau HS produk kopi tertentu dari ekspor kopi Indonesia.

Seluruh produk kopi dan turunannya berdasarkan klasifikasi HS yang diamati merupakan ekspor aktif, (nilainya selalu positif selama periode 1994-2013). Dengan demikian, seluruhnya termasuk dalam kategori produk lama.

Secara total terdapat 18 jenis produk ekspor kopi yang diekspor Indonesia dalam kategori HS sembilan digit pada tahun 1994. Namun demikian, selama tahun 2008 hingga tahun 2013, hanya terdapat 15 jenis produk dalam kategori HS sepuluh digit. Tercatat ada enam kelompok HS sembilan digit yang hilang, namun ada penambahan tiga kelompok HS sepuluh digit yang berupa pemecahan dari HS sembilan digit. Dengan tidak adanya kelompok HS produk baru dalam ekspor Indonesia, maka keseluruhan marjin berasal dari ekspor produk lama.

\section{Marjin Intensif}

Marjin intensif untuk produk kopi dan turunannya di Indonesia dijelaskan melalui ekspor produk lama ke negara tujuan lama. Marjin intensif menjelaskan pertumbuhan atau penurunan ekspor secara dominan, yaitu berkisar antara 83-98\% (Gambar 9). Ekspor marjin produk intensif terutama didominasi biji kopi. Namun memiliki kecenderungan berkurang, seiring dengan peningkatan peran marjin ekstensif terutama setelah tahun 2006. 


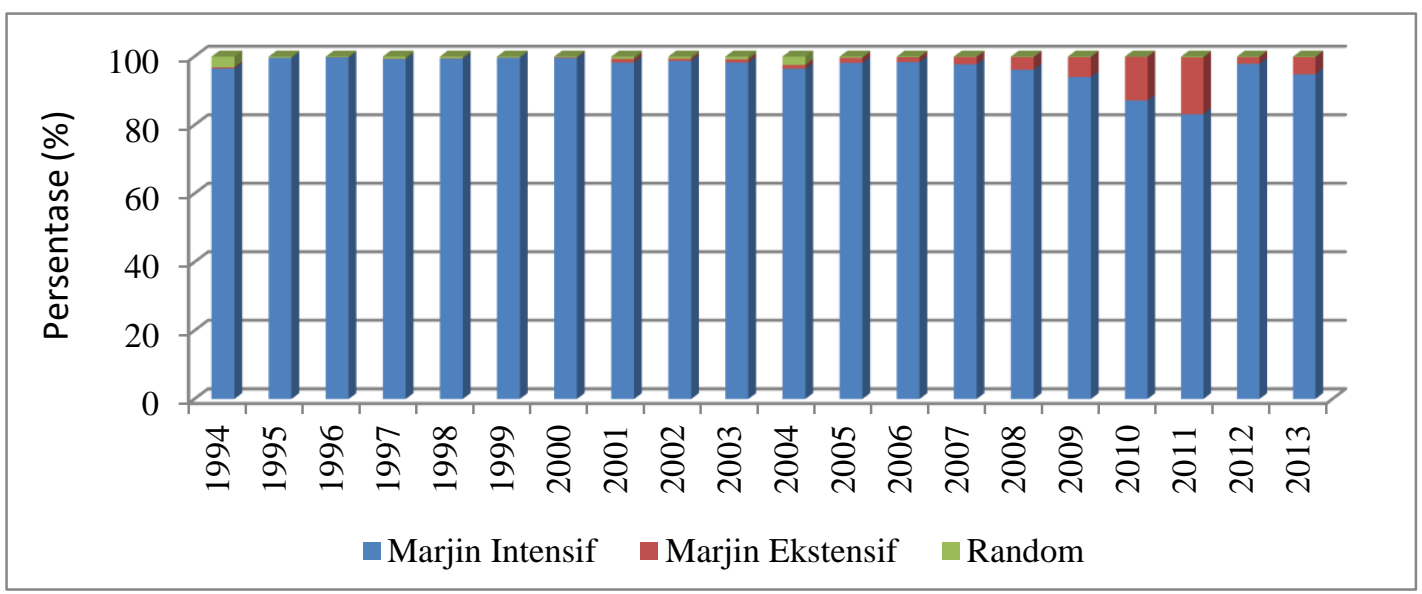

Sumber : BPS, 2014 (Diolah)

Gambar 9 Komposisi marjin ekspor kopi Indonesia, 1994-2013

\section{Marjin Ekstensif}

Walaupun sebagian besar pertumbuhan ekspor dijelaskan melalui marjin intensif, namun terdapat perkembangan dari marjin ekstensif yang menandakan diversifikasi ekspor. Pada tahun 2010-2011, marjin ekstensif meningkat hingga $12-16 \%$, mendorong kontribusi marjin intensif menjadi $87 \%$ dan $83 \%$.

Secara umum, marjin ekstensif memang bernilai kecil. Terdapat paling tidak dua alasan mengapa marjin ekstensif kecil, yaitu teknis dan substansial. Alasan substansial yaitu, suatu produk yang diekspor pada tahun pertama menjadi produk baru namun demikian tidak demikian pada tahun-tahun berikutnya.

Alasan teknis adalah karena sulitnya produk baru untuk masuk ke pasaran dan bertahan. Selain itu, dengan semakin terbukanya perdagangan, dapat dikatakan semua produk telah diperdagangkan dengan semua negara. Namun, menurut Amiti dan Freund (2007) yang menganalisa komposisi pertumbuhan ekonomi China, ekonomi China tumbuh $450 \%$ selama periode 1996-2006, yang salah satunya didukung pertumbuhan ekspor manufaktur. Dari sisi produk, 5-15\% pertumbuhan ekspor
China dijelaskan melalui marjin ekstensif.

Dengan tidak adanya produk baru dalam ekspor kopi Indonesia, maka marjin ekstensif dijelaskan oleh ekspor ke negara tujuan baru. Diversifikasi negara tujuan terjadi di tiga kelompok kopi yang diteliti. Untuk biji kopi, diversifikasi negara tujuan ekspor terjadi ke dua belas negara yaitu Thailand, Ukraine, Latvia, Israel, Estonia, Iceland, Russia, Algeria, Georgia dan India, serta (Malaysia dan Amerika Serikat untuk produk kulit kopi). Diversifikasi negara terbesar untuk produk ini adalah Thailand dengan nilai ekspor dibawah HS 0901111000 sebesar US\$ 48,39 juta di tahun 2013 atau mencapai 95\% dari total diversifikasi negara tujuan biji kopi. Thailand awalnya merupakan produsen kopi, dan pada tahun 1976 mulai mengekspor kopi jenis robusta. Dengan insentif berupa harga kopi yang tinggi di tahun 1980an, ekspor kopi Thailand mencapai puncaknya di tahun 1991/92 dengan 60.000 ton. Namun, dengan terbukanya pasar bebas untuk kopi dan oversupply yang menjatuhkan harga kopi secara internasional, Pemerintah Thailand meluncurkan program lima tahun sejak tahun 1992 agar petani kopi mengganti kopi dengan tanaman lain, 
antara lain karet dan sawit karena harga pasar yang lebih tinggi.

Konsumsi per kapita sekitar 200 gelas per tahun di Thailand yang tergolong rendah bila dibandingkan konsumsi Jepang (500 gelas) dan Amerika Serikat (700-800 gelas). Namun, konsumsi kopi domestik di Thailand diperkirakan mencapai 70.000 ton per tahun dengan pertumbuhan mencapai $10 \%$ per tahun. Pasar kopi di Thailand didominasi dengan kopi instan dan kopi kemasan mix (three in one) dengan perputaran mencapai 30 Milyar Baht atau sekitar US\$ 900 juta. Dalam rangka memenuhi konsumsi kopi instan, Thailand mengimpor 25.000 ton untuk industri pembuatan kopi instan domestik. Saat ini dengan konsumsi yang melebihi produksi, Thailand merupakan net-importer kopi dan produk olahannya. Sumber impor kopi Thailand antara lain Indonesia dan Vietnam. Thailand saat ini mengembangkan kopi spesialti dengan mencampur kopi yang diproduksi domestik dengan impor. Dengan demikian, diversifikasi negara tujuan produk biji kopi ke Thailand dianggap kurang menguntungkan.

Walaupun diversifikasi negara tujuan ekspor kopi sangrai terjadi ke 18 negara yaitu Russsia Fed, Algeria, Georgia, India, United States of Amerika, Malaysia, Guam, Republic of Korea, United Arab Emirates, Germany, Belgium, Brunei Darussalam, Jordan, Spain, Turkey, Bulgaria, Greece, dan Lebanon, namun diversifikasi untuk produk kopi sangrai dapat dikatakan kurang berhasil, karena dari jumlah tidak meningkat dengan baik selama pengamatan 20 tahun. Hal ini sesuai dengan penjabaran struktur dan kinerja ekspor kopi sangrai. Peran terbesar diversifikasi produk ini terjadi di periode 2004-2006, yang terutama dipicu peningkatan ekspor ke Spain, Turkey, dan Bulgaria.
Spain merupakan pasar ekspor yang aktif untuk ekspor kopi Indonesia secara keseluruhan sejak tahun 1994. Namun untuk jenis kopi sangrai, ekspor Spain dari Indonesia dimulai di bawah HS 0901121000, sebesar US\$ 46.950 pada tahun 2004. Konsumsi kopi domestik di Spain didominasi kopi sangrai $(82,4 \%)$ dari total konsumsi dan sisanya konsumsi kopi ekstrak. Sumber impor utama Spain antara lain Vietnam, Brazil, Uganda, Jerman dan Colombia.

Di Turkey, kopi instan mendominasi konsumsi sekitar 83,9\% dari total konsumsi domestik dan sisanya, namun terjadi pertumbuhan konsumsi yang cukup baik yang didorong konsumsi kawula muda sebagai bagian dari kehidupan sehari-hari. Untuk Bulgaria, pertumbuhan konsumsi cukup stabil karena pasar kopi di negara tersebut telah memasuki tahap dewasa. Beberapa faktor yang mempengaruhi pasar kopi Bulgaria di masa mendatang adalah jumlah penduduk yang turun, pendapatan yang meningkat pelan namun budaya minum kopi terus tumbuh, walaupun mutu kopi yang dikonsumsi saat ini masih lebih rendah dari kopi kawasan Eropa Barat. Namun demikian, ekspor kopi sangrai ke ketiga negara tersebut tidak berkembang, dan berhenti di tahun 2008 .

Tujuan ekspor utama untuk produk ekstrak kopi Indonesia adalah Asia, terutama Philippines. Ekspor produk ekstrak kopi Indonesia ke Phillipines dimulai di tahun 2003 sebesar US\$ 43 ribu. Dengan tren sebesar $71,16 \%$ per tahun, ekspor tersebut pada tahun 2013 mencapai US\$1,23 juta. Philippines sendiri merupakan net-importir kopi dengan pertumbuhan konsumsi terbesar di Asia Tenggara dengan konsumsi per tahun mencapai 100 ton.

Tujuan lainnya adalah China yang konsumsi domestiknya didominasi 
produk ekstrak. Walaupun terkenal sebagai negara teh, kopi masuk diiringi terbukanya ekonomi China dan perilaku meniru budaya barat. Euromonitor mem-perkirakan pasar kopi di China mendekati 50 milyar RMB di tahun 2018. Ekspor Indonesia untuk produk ekstrak kopi dimulai pada tahun 2008 sebesar US\$ 48 ribu dan mencapai US\$ 3,93 juta pada tahun dengan pertumbuhan per tahun mencapai $151,59 \%$ selama 2008-2013.

Selain Asia, Timur Tengah yang diwakili Lebanon juga merupakan salah satu negara tujuan untuk produk kopi ekstrak Indonesia. untuk produk ekstrak kopi, nilai ekspor Indonesia ke Lebanon sebesar US\$ 26 ribu dimulai di tahun 2006, dan tumbuh sebesar $89,09 \%$ per tahun selama periode 2006-2013, sehingga mencapai US\$ 4,54 juta. Berdasarkan Euromonitor, Lebanon merupakan pasar potensial di masa mendatang, terutama untuk produk konsumsi.

Secara umum, diversifikasi ekspor produk kopi ekstrak terjadi untuk 27 negara tujuan ekspor. Namun tiga negara besar adalah Philippines, China dan Lebanon. Tiga negara ini juga merupakan importir penting produk kopi ekstrak di bawah kategori HS 210112000 (Preparations with a basis of extracts, basis of coffee).

\section{Marjin Hilang}

Terdapat beberapa perbedaan dalam pencatatan kode HS sembilan digit dengan sepuluh digit untuk produk kopi. Pada HS sembilan digit, terdapat pembedaan dari sisi jenis kopi dan cara pengolahannya. Secara umum, produk kopi yang diekspor Indonesia adalah kopi jenis arabika dan robusta. Dari sisi pengolahannya, buah kopi diolah menjadi biji kopi melalui cara basah (West Indische Bereiding/WIB) atau cara kering (Oost Indische Bereiding/OIB).
Perbedaan dari segi teknis tidak akan dibahas pada penelitian ini, namun perbedaan cara pengolahan memiliki implikasi pada sisi biaya. Pengolahan dengan cara basah (WIB) memiliki tahapan proses yang lebih panjang, antara lain fermentasi, pencucian dan pengeringan. Dengan demikian, maka pengolahan dengan cara basah memerlukan peralatan lebih dan biaya yang lebih mahal. Umumnya pengolahan dengan cara basah WIB dilakukan oleh perusahaan menengah besar, sedangkan cara kering dilakukan oleh perusahaan menengah kecil. Selain itu, pengolahan dengan cara basah WIB umumnya lebih dilakukan untuk kopi dengan jenis yang harganya lebih tinggi, yaitu arabika. Pengelompokkan dalam HS sembilan digit mengakomodir ekspor biji kopi menjadi tiga kelompok HS yaitu arabika OIB, arabika WIB, robusta OIB dan lainnya.

Dari sisi produk, marjin hilang terutama dari dari kelompok produk kopi sangrai. Ekspor kopi sangrai meliputi lima HS sembilan digit dan empat HS sepuluh digit, yang meliputi kopi bubuk dan kopi mengandung atau tidak mengandung kafein. Pada tahun 1995, ekspor kopi kafein rendah jenis arabika yang diproses dengan cara kering/OIB (HS 090111100), menghilang dari ekspor Indonesia. Namun selanjutnya pada tahun 1998, kopi kafein rendah jenis arabika WIB mulai memasuki pasar ekspor. Namun demikian, nilai ekspornya terus turun hingga hanya memiliki pangsa $0,02 \%$ dari keseluruhan nilai ekspor kopi.

Selain itu kopi kafein rendah robusta OIB pun tidak kompetitif di pasar ekspor. Nilainya terus menurun dengan tren penurunan $49,34 \%$ per tahun dari tahun 1994-2005. Produk ini pun tidak lagi diekspor sejak tahun 2007. Dengan demikian, ekspor Indonesia 
semakin terkonsentrasi ke ekspor kopi jenis robusta.

\section{c. Analisis Data Panel dengan Model Gravity}

Analisis gravity dilakukan untuk menentukan faktor-faktor yang mempengaruhi diversifikasi ekspor produk kopi. Berdasarkan hasil dekomposisi didapatkan kesimpulan bahwa produk kopi olahan yang memiliki peluang untuk diversifikasi adalah kopi ekstrak. Dengan demikian, produk yang dipilih untuk pemodelan adalah kopi ekstrak di bawah HS 210112000 (Preparations with a basis of extracts, basis of coffee).

Adapun negara tujuan diversifikasi ekspor kopi ekstrak yang dipilih terdiri dari tiga negara, yaitu Philippines, China dan Lebanon. Ketiganya dipilih berdasarkan pertimbangan bahwa selain nilai diversifikasi ekspornya dari Indonesia tinggi, nilai impornya dari dunia juga tinggi. Secara global, Impor kopi ekstrak dimaksud dapat dilihat pada Tabel 2.

Tabel 2. Impor HS 210112000 (Preparations with a basis of extracts, basis of coffee)

\begin{tabular}{|c|c|c|c|c|c|c|}
\hline \multirow{2}{*}{ No. } & \multirow{2}{*}{ Importir } & \multicolumn{3}{|c|}{ Nilai Impor (Ribu US\$) } & \multirow{2}{*}{$\begin{array}{l}\text { Pangsa } \\
\text { (2014) \% }\end{array}$} & \multirow{2}{*}{$\begin{array}{c}\text { Tren\% } \\
(2001-2014)\end{array}$} \\
\hline & & 2012 & 2013 & 2014 & & \\
\hline & World & 1.491 .346 & 1.609 .391 & 1.750 .599 & 100 & 15,4 \\
\hline 1 & Philippines & 84.733 & 77.326 & 147.725 & 8,4 & 32,6 \\
\hline 2 & China & 41.140 & 62.184 & 142.654 & 8,1 & 43,4 \\
\hline \multirow[t]{2}{*}{32} & Lebanon & 13.640 & 12.429 & 18.183 & 1,0 & 23,6 \\
\hline & Lainnya & 1.347 .442 & 1.454 .565 & 1.442 .037 & 82,4 & 14,4 \\
\hline
\end{tabular}

Sumber : Trademap, 2015

Analisis dengan model gravity dimulai dengan memilih estimasi, apakah PLS, FE atau RE dalam rangka memperoleh model yang layak dan estimasi yang bersifat BLUE (Best Linier Unbiased Estimator), kemudian menganalisis faktor-faktor yang mempengaruhi diversifikasi ekspor kopi Indonesia. Model yang cocok diperole dilakukan uji kelayakan dan kecocokan model (goodness of fit). Untuk memperoleh estimasi yang bersifat BLUE maka dilakukan juga pengujian asumsi dasar. Hasil estimasi yang menggunakan gravity model tersebut dilakukan dengan program software Stata 12.

\section{Hasil Estimasi Model Data Panel}

Analisis faktor yang mempengaruhi diversifikasi ekspor produk kopi ekstrak Indonesia ke negara tujuan ekspor utama menggunakan panel data statis pada gravity model dari tahun
1994-2013. Hasil uji Chow menunjukkan bahwa Fixed Effect Model (FEM) lebih baik daripada Pooled Least Square (PLS) yang dilihat dari nilai F-restricted (Prob $>\mathrm{F}=0,0095)$ yang terdapat pada hasil olahan STATA untuk fixed effect regression. Uji Breusch Pagan LM memberikan hasil bahwa Random Effect Model (REM) lebih baik dari PLS dengan nilai statistik sebesar 0,00 (Prob>chibar2=1,0000).

Berdasarkan kedua pengujian tersebut, maka dilakukan uji Hausman untuk menentukan model $\mathrm{FE}$ atau RE yang akan digunakan pada penelitian ini. Hasil uji Hausman menunjukkan bahwa FEM merupakan model yang cenderung lebih baik dari REM dengan nilai statistik sebesar 10,88 (Prob>Chi Square $=0,0537$ ) sehingga model yang dipilih dalam penelitian ini adalah Fixed Effect Model. 


\section{Uji Kelayakan dan Kecocokan Model (Goodness of fit)}

Hasil uji kelayakan ditunjukkan dari nilai probability ( $F$-Statistic) model yang digunakan. Untuk model FEM yang dipilih Prob> F=0.0000 sehingga dapat disimpulkan bahwa minimal terdapat satu variabel bebas yang mempengaruhi variabel tidak bebas dan model layak untuk digunakan. Uji kecocokan model (goodness of fit) ditunjukkan pada nilai koefisien determinasi $\left(\mathrm{R}^{2}\right)$. Model menunjukkan nilai $\mathrm{R}^{2}$ sebesar 0,8466 yang berarti sebanyak $84,66 \%$ variasi variabel bebas mampu menjelaskan variabel tak bebas sebesar, sedangkan sisanya dijelaskan oleh faktor-faktor lainnya diluar model.

\section{Uji Asumsi Dasar}

Uji asumsi dasar dilakukan untuk memperoleh estimasi yang bersifat BLUE (Best Linier Unbiased Estimator). Uji asumsi dasar ini meliputi uji multikolinearitas, heteroskedastisitas, dan autokorelasi. Uji multikoleniaritas pada olahan STATA dapat dilihat dari nilai VIF. Jika nilai VIF lebih besar dari sepuluh, atau 1/VIF lebih kecil dari satu, maka model mengandung mulkoleniaritas. Dengan nilai Mean VIF yang lebih besar dari sepuluh, dapat disimpulkan bahwa antar variabel yang diteliti terjadi multikolinearitas.

Tabel 3 Uji Multikoleniaritas

\begin{tabular}{|c|c|c|}
\hline \multicolumn{3}{|l|}{ vif, uncentered } \\
\hline Variable & VIF & 1/VIF \\
\hline log_gdpp & 548.03 & 0.001825 \\
\hline log_ecodis & 339.25 & 0.002948 \\
\hline log_gdpind & 321.49 & 0.003110 \\
\hline $\log _{\text {cour }}$ & 57.52 & 0.017385 \\
\hline dagree & 4.25 & 0.235158 \\
\hline Mean VIF & & 11 \\
\hline
\end{tabular}

Uji heteroskedastisitas dilihat dari hasil Modified Wald Test. Dari hasil uji, dapat dilihat bahwa model mengalami heteroskedastisitas yang ditunjukkan dengan nilai wald test lebih kecil dari $\alpha$ $(0,05)$.

Tabel 4 Uji Heteroskedastisitas

Modified Wald test for groupwise heteroskedasticity in fixed effect regression model

H0: $\operatorname{sigma}(\mathrm{i})^{\wedge} 2=\operatorname{sigma}^{\wedge} 2$ for all $\mathrm{i}$

$\operatorname{chi} 2(3)=24,43$

Prob $>$ chi $2=0,0000$

Uji autokorelasi dapat dilihat dari hasil Wooldridge test. Menurut hasil uji, model tidak mengandung autokorelasi yang ditunjukkan dengan nilai F-Stat lebih besar dari $\alpha(0,05)$.

Tabel 5 Uji Autokorelasi

\begin{tabular}{l}
$\begin{array}{l}\text { Wooldridge test for autocorrelation in panel } \\
\text { data }\end{array}$ \\
\hline H0: no first-order autocorrelation \\
$\qquad$\begin{aligned} &$F(1,2)= 4,304 \\
&$ Prob $>\mathrm{F}= 0,1737 \\
&$\hline\end{aligned}
\end{tabular}

Untuk mengatasi masalah heteroskedastik dan multikoleniaritas pada model FE yang dipilih, maka digunakan model panel FE dengan General Least Square (GLS) yang mengatasi pelanggaran asumsi tersebut.

Tabel 6 Output Model

Cross-sectional time-series FGLS regression

Coefficients : generalized least squares

Panels : homoskedastic

Correlation : no autocorrelation

\begin{tabular}{lcr}
\hline \multicolumn{1}{c}{ log_exp } & Coef. & \multicolumn{1}{c}{ P>z } \\
\hline log_gdpp*** & $-3,260231$ & 0,116 \\
log_gdpind* & 7,35292 & 0,000 \\
dagree* & 3,156758 & 0,000 \\
log_ecodis &,- 6976862 & 0,860 \\
log_cur* & 1,797272 & 0,046 \\
_cons & $-74,97423$ & 0,000 \\
\hline Ket : Tanda $*$ * **, *** & berturut-turut \\
menunjukkan signifikansi pada keyakinan 5, 10 \\
dan 15\% dimana:
\end{tabular}




$$
\begin{aligned}
& \exp =\text { nilai ekspor pada marjin } \\
& \text { ekstensif dari Indonesia ke } \\
& \text { Negara tujuan-d, untuk } \\
& \text { produk i dalam kategori HS } \\
& 10 \text { digit di tahun- } t \\
& \text { gdppd = GDP per kapita Negara } \\
& \text { tujuan-d di tahun-t } \\
& \text { gdpind }=\text { GDP Indonesia di tahun- } \mathrm{t} \\
& \text { dagree }=\text { dummy kerjasama } \\
& \text { perdagangan bernilai } 1 \text { bila } \\
& \text { terdapat kerjasama } \\
& \text { perdagangan dengan negara } \\
& \text { tujuan di tahun-t dan bernilai } \\
& 0 \text { bila tidak terdapat } \\
& \text { kerjasama dengan negara } \\
& \text { tujuan di tahun-t }
\end{aligned}
$$

\section{Faktor yang Mempengaruhi Ekspor Kopi Ekstrak Indonesia di Negara Tujuan Diversifikasi}

Berdasarkan hasil pengujian model dengan menggunakan FGLS, diperoleh hasil bahwa nilai ekspor produk kopi ekstrak Indonesia ke tiga Negara tujuan diversifikasi dipengaruhi oleh GDP per kapita negara pengimpor, jarak ekonomi, nilai tukar, dan dummy perdagangan internasional (kebijakan FTA untuk China dan Philippines dalam kerangka ASEAN). Variabel GDP per kapita Negara tujuan diversifikasi merupakan faktor yang mewakili variabel permintaan. Variabel ini secara teori memiliki hubungan yang positif dengan arus ekspor. Artinya saat pendapatan per kapita negara tujuan diversifikasi meningkat diharapkan permintaan akan ekspor dari Indonesia pun meningkat. Demikian juga halnya dengan variabel GDP Indonesia yang mewakili variabel pernawaran.

\section{GDP Per Kapita Negara Pengimpor}

Variabel GDP per kapita diharapkan dapat mewakili aktivitas ekonomi, tingkat konsumsi dan daya beli Negara tujuan ekspor. Pada model, GDP per kapita negara pengimpor memiliki hubungan negatif terhadap arus perdagangan ekspor CPO Indonesia. Hasil penelitian ini berseberangan dengan teori permintaan untuk barang normal. Dengan nilai koefisien sebesar $-3,26$, dapat disimpulkan bahwa jika terjadi peningkatan GDP per kapita negara pengimpor sebesar $1 \%$ maka pengaruhnya akan menurunkan ekspor kopi ekstrak Indonesia sebesar 3,26\%, ceteris paribus. Peningkatan pendapatan yang terjadi pada negara pengimpor justru berdampak negatif terhadap diversifikasi ekspor produk kopi ekstrak Indonesia. Hal ini mengindikasikan bahwa kopi ekstrak Indonesia merupakan barang inferior di negara tujuan diversifikasi.

Beberapa penjelasan mengenai hal ini adalah bergesernya selera pasar, saat terjadi peningkatan pendapatan. Kopi berbahan dasar robusta seringkali dianggap sebagai kopi berkualitas rendah, terkait dengan rasa getir yang dimilikinya. Kopi arabika merupakan kopi yang lebih digemari karena memiliki cita rasa yang lebih sesuai. Namun demikian, penggunaan kopi robusta meningkat seiring dengan peningkatan teknologi, dan dapat digunakan untuk campuran, bukan bahan pokok.

Seiring dengan terjadinya globalisasi, maka selera pasar semakin konvergen dan menjadi semakin homogen. Hal ini banyak disebutkan dalam berbagai literatur yang membahas dampak globalisasi, salah satunya dalam Holton (2000). Dengan demikian, selera pasar akan lebih terstandar dan umumnya mengarah pada westernization atau perilaku meniru budaya barat, 
termasuk dari segi konsumsi. Selera konsumsi di negara maju yaitu semakin meninggalkan konsumsi kopi ekstrak dan menuju ke arah konsumsi kopi segar dan sangrai berbahan dasar arabika.

Hal ini juga didukung dengan banyaknya dibuka gerai kopi di negara berkembang seiring dengan meningkatnya coffee culture di Asia Pasifik, negara produsen dan negara berkembang, Hal ini karena pasar kopi telah mencapai masa yang matang, dan pertumbuhan konsumsi kopi didukung konsumsi negara produsen dan negara berkembang (ICO, 2014)

Peningkatan pendapatan me-mungkinkan masyarakat di Negara tujuan diversifikasi berubah konsumsi dari kopi ekstrak yang cita rasanya lebih digemari menjadi kopi berbahan dasar arabika yang lebih mahal. Bukti empiris mengenai perubahan selera yang akhirnya mengubah pola konsumsi kopi juga disebutkan dalam Ponte (2002). Pada tahun 1980an, konsumen di Amerika Serikat secara progresif beralih konsumsinya dari kopi ekstrak yang berbahan dasar robusta ke kopi ground yang berbahan dasar arabika.

Dengan demikian, walaupun variabel GDP per kapita negara tujuan ini signifikan di level 15\% (P-value = $11 \%$ ), namun pengaruhnya terhadap diversifikasi ekspor kopi ekstrak Indonesia dapat dijelaskan secara logis.

\section{Jarak Ekonomi (Distance)}

Jarak ekonomi merupakan pendekatan yang digunakan untuk mengukur biaya ekspor. Jarak ekonomi merupakan syarat penting pada gravity model dan besarnya jarak ekonomi akan mempengaruhi arus perdagangan ekspor secara negatif atau menghambat aliran perdagangan. Hasil estimasi yang diperoleh model menunjukkan bahwa variabel jarak ekonomi tidak berpengaruh signifikan terhadap ekspor.
Pada berbagai penelitian yang menggunakan model gravity, jarak ekonomis diharapkan memiliki pengaruh yang signifikan. Artinya arus perdagangan dan keputusan ekspor-impor dipengaruhi oleh jarak relatif, yang salah satunya berupa jarak ekonomi. Namun demikian, bila komponen ekspor diagregasi ke dalam bentuk marjin ekspor, maka bisa menghasilkan hasil yang berbeda.

Pemodelan yang mengagregasi marjin ekspor menghasilkan kesimpulan bahwa jarak ekonomis tidak berpengaruh terhadap nilai ekspor pada marjin ekstensif. Penjelasan mengenai hal ini adalah bahwa diversifikasi tidak mengalami batasan dalam hal jarak.

\section{GDP Indonesia}

GDP Indonesia merupakan variabel yang diharapkan dapat mewakili seluruh aktivitas ekonomi pendukung penawaran dan dengan demikian mewakili faktor penawaran ekspor kopi ekstrak dari Indonesia.

Nilai koefisien variabel GDP Indonesia bernilai positif sebesar 7,35. Hal ini mengindikasikan jika populasi negara pengimpor meningkat $1 \%$ maka nilai ekspor kopi ekstrak ke negara tujuan diversifikasi akan meningkat sebesar $7,35 \%$, ceteris paribus. Kondisi ini sesuai dengan hipotesis penelitian yang menjelaskan bahwa GDP Indonesia berpengaruh positif pada ekspor Indonesia.

Pengaruh sisi penawaran terhadap diversifikasi ekspor antara lain dijelaskan dalam Hesse (2008). Salah satu contoh yang dijelaskan adalah kasus Uganda, negara yang landlocked dan miskin infrastruktur. Diversifikasi menjadi berkembang karena berkembangnya sistem pengakutan hingga terjadi reduksi besar pada biaya kargo. Dan juga pengembangan penggunaan sistem cold storage. 
Pembahasan tentang diversifikasi ekspor di Indonesia dari sisi penawaran juga dijelaskan dalam Siregar dan Daryanto (2005). Diversifikasi dilihat dari variabel ukuran resiko yang menandakan volatilitas perekonomian Indonesia dan foreign direct Investment.

GDP Indonesia merupakan variabel yang paling berpengaruh terhadap diversifikasi ekspor kopi ekstrak. Dengan demikian, variabel penawaran merupakan faktor penentu bagi keberhasilan diversifikasi ekspor negara tujuan dibanding faktor lainnya. Hal ini bersesuaian dengan Tarman (2007) dalam hasil FGD (Focus Group Discussion) dengan pihak pengusaha yang mengungkapkan berbagai permasalahan terkait ekspor dan perluasan ekspor. Permasalahan yang diungkapkan lebih banyak bersumber dari sisi penawaran, antara lain biaya-biaya meliputi bahan baku, tenaga kerja, energi, pungutan daerah dan biaya tak resmi, ketersediaan bahan baku dan infrastruktur yang kesemuanya telah terangkum dalam variabel GDP.

\section{Nilai Tukar (Exchange Rate)}

Secara teori, saat mata uang negara pengekspor terdepresiasi atau nilai tukarnya meningkat dibandig mata uang negara lain maka akan mengakibatkan harga produk di negara pengekspor menjadi lebih murah sehingga mendorong permintaan produk dari negara lain. Hal ini sesuai dengan penelitian yang dilakukan oleh Zarzoso dan Lehmann (2003) yang menyatakan bahwa terjadinya depresiasi mata uang di negara pengekspor akan dapat menaikkan ekspor. Walaupun demikian, saat terjadinya depresiasi nilai rupiah saat krisis finansial, tidak terdapat kenaikan ekspor Indonesia. Kenaikan ekspor baru terjadi setelah sekian waktu (lag) dan dalam nilai yang relatif kecil. Dengan demikian, pengaruh nilai tukar terhadap ekspor tidak berdiri sendiri dan hasilnya dapat berbeda-beda.

Berdasarkan hasil estimasi diperoleh kesimpulan bahwa model menunjukkan bahwa nilai tukar berpengaruh signifikan terhadap ekspor dengan taraf nyata 5\% dan besaran koefisiennya yaitu 1,79. Hal tersebut berarti jika terjadi peningkatan nilai tukar sebesar $1 \%$ maka akan meningkatkan $1,79 \%$ ekspor produk kopi ekstrak ke negara tujuan diversifikasi, ceteris paribus.

Hasil ini tidak sesuai dengan hasil yang didapat Anggraini (2007) yang meneliti tentang arus ekspor produk kopi Indonesia ke Amerika Serikat. Hasil yang diperoleh, nilai tukar tidak berpengaruh signifikan terhadap arus ekspor. Penjelasan mengenai hal ini antara lain didapat melalui penelitian Taglioni (2012) dan Yi Lin (2007). Keduanya menyatakan bahwa banyak temuan empiris terkini yang menghasilkan kesimpulan kecilnya pengaruh nilai tukar terhadap ekspor atau bahkan pengaruhnya tidak signifikan sama sekali. Namun, hubungan antara mata uang dengan ekspor bisa menunjukkan arah yang berbeda saat ekspor didisagregasi menjadi marjin ekstensif dan marjin intensif. Kedua marjin tersebut dapat bekerja dengan arah yang berlawanan terhadap pergerakan nilai tukar. Ketidakpastian dari nilai tukar cenderung memberi dampak negatif pada marjin ekstensif dan memberikan dampak positif pada marjin intensif.

Hasil yang diperoleh pada penelitian ini, tidak sampai menyimpulkan tentang ketidakpastian nilai tukar terhadap marjin ekstensif. Dalam hal ini nilai ekspor pada marjin ekstensif diuntungkan dengan melemahnya nilai tukar. Dengan pengaruh tingginya konten lokal dalam produk ekstrak kopi (bahan baku robusta 
domestik), produksi dan ekspor kopi ekstrak tidak perlu mengandalkan bahan baku impor, berbeda dengan produk manufaktur lain yang membutuhkan impor bahan baku atau bahan penolong tertentu sebelum menjadi barang ekspor.

Selain itu, hasil yang diperoleh memberikan implikasi bahwa produk kopi ekstrak Indonesia turut mengandalkan price competitiveness untuk masuk ke negara tujuan diversifikasi ekspor. Price competitiveness tersebut berasal dari melemahnya nilai tukar Indonesia terhadap negara tujuan diversifikasi ekspor kopi ekstrak, sehingga harganya cenderung menurun dibanding harga lokal di negara tujuan diversifikasi ekspor.

\section{Kerjasama Perdagangan}

Variabel selanjutnya adalah yang mendukung atau menghambat aliran perdagangan, yaitu tarif dan nilai tukar. Secara teori, tarif merupakan penghambat aliran perdagangan dan dengan demikian memiliki pengaruh negatif terhadap ekspor. Dikarenakan data yang tidak tersedia secara lengkap untuk tarif produk dimaksud di negara tujuan, maka sebagai gantinya digunakan dummy kerjasama perdagangan.

Kerjasama perdagangan antara Indonesia dan Philippines yang dimaksud adalah dalam kerangka ASEAN. Produk kopi dalam HS 21 yang masuk ke Philippines tercatat dikenakan tarif 50-55\% pada tahun 1996 dengan demikian periode kerja sama perdagangan dalam rangka penurunan tarif adalah pada kasus ketiga, yaitu penurunan tarif menuju $0-5 \%$ terjadi di tahun 2003.

Demikian juga kerja sama perdagangan Indonesia-China dalam kerangka ASEAN-China FTA. Namun demikian, skema penurunan tarif pertama untuk penurunan tarif adalah pada Agustus tahun 2007. Sedangkan dengan Lebanon, Indonesia tidak memiliki kerjasama perdagangan selama periode 1994-2013.

Kerjasama perdagangan diharapkan menjadi salah satu representasi penurunan tarif, dan juga mewakili pengurangan terhadap hambatan perdagangan non-tarif lainnya. Dengan adanya adanya kerjasama, nilai diversifikasi ekspor produk kopi ekstrak mengalami peningkatan sebesar $3,15 \%$. Dengan demikian, tarif dalam ini bersesuaian dengan teori, menjadi penghambat dalam aliran perdagangan.

\section{KESIMPULAN DAN SARAN}

\section{Kesimpulan}

Berdasarkan uraian diatas maka dapat disimpulkan bahwa:

1. Ekspor kopi Indonesia dapat dibagi kedalam tiga kelompok yaitu kopi biji, serta kopi sangrai dan kopi ekstrak. Sejak periode 1994-2013, ekspor kopi Indonesia masih didominasi kopi biji. Secara internasional, biji kopi sebagai komoditas harganya sangat fluktuatif dan mudah diguncang situasi pasar, terutama sejak liberalisasi pasar kopi diberlakukan pada tahun 1990. Biji kopi yang dihasilkan Indonesia didominasi jenis robusta yang dianggap kopi kelas dua di pasar internasional. Selain itu, ekspor robusta juga dalam kategori mutu yang kurang bersaing. Hal ini menyebabkan fluktuasi nilai ekspor kadang tinggi dan tidak terkendali dan sangat mempengaruhi kinerja ekspor kopi Indonesia. Namun demikian, produk olahan kopi terutama ekstrak kopi mulai muncul sebagai 
pendorong pertumbuhan ekspor, terutama setelah tahun 2006.

2. Produk kopi yang mengalami diversifikasi dan mendorong pertumbuhan ekspor adalah kopi ekstrak dengan diversifikasi ke tiga negara tujuan yaitu Philippines, China dan Lebanon. Ekspor ekstrak kopi ke negara tujuan diversifikasi tersebut dipengaruhi secara positif oleh GDP Indonesia, nilai tukar dan kerjasama perdagangan yang merepresentasi tarif dan hambatan perdagangan.

\section{Saran}

Beberapa hal yang dapat disarankan berdasarkan uraian pada penelitian ini adalah:

1. Indonesia sebaiknya memulai untuk membangun industri pengolahan, terutama untuk kopi ekstrak.

2. Konversi penanaman jenis kopi arabika perlu dilakukan dan usaha untuk menghasilkan produk yang lebih baik kualitasnya

3. Menyelenggarakan kerjasama perdagangan dengan negara berkembang yang merupakan konsumen kopi, salah satunya Lebanon

4. Memperbaiki sisi penawaran dengan mengatasi hambatan ekspor yang dialami pengusaha.

\section{DAFTAR PUSTAKA}

Zarzoso IM, Lehman FN. 2003. Augmented Gravity Model: An Empirical Application to Mercosur-European Union Trade Flows. Journal of Applied Economics VI (2): 291-316.

Holton R. 2000. Globalization Culture's consequences. Annals of the American Academy of Political and Social Science. Vol. 570., Dimensions of Globalization: Sage Publication, Inc.

, 2011. The Coffee Exporter's Guide THIRD EDITION. International Trade Center. Geneva

, 2014. World Coffee Trade (1963-2013): A review of the markets, challenges and opportunities facing the sector. International Coffee Organization. Presented in International Coffee Council $112^{\text {th }}$ session. London, UK Amiti F. 2007. An anatomy of China's Export Growth. IMF

Amurgo-Pacheco, Pierola. 2008. Patterns of Export Diversification in Developing Countries. Research Working Paper 4473. World Bank.

Firdaus M. 2011. Aplikasi Ekonometrika untuk Data Panel dan Time Series. Bogor: IPB Press.

Gujarati, Damodar. 2007. "Dasar-dasar Ekonometrika". Erlangga, Jakarta

Gunadi. 2007. Social Impact of Coffee Crisis on the Pasemah coffee farmers in South Sumatera. MPRA Paper No. 12624, posted. http://mpra.ub.uni-muenchen.de/1 2624/ [9. January 2009].

Hutabarat B. 2010. World Market Condition and It's Impact in the Performance of National Coffee Industry. Indonesian Journal of Agriculture 3(1), 2010 : 51-59

Ottaway A. 2007. A Rapid Assesment of the Specialty Coffee Value Chain in Indonesia. US Agency for International Development. A Project Implemented by 
Development Alternatives, Inc. USAID Indonesia

Ponte, S. 2002. The 'Latte Revolution'? Regulation, Markets and Consumption in the Global Coffee Chain. Journal of World Development Vol. 30, No. 7, pp. 1099-1122. Elsevier Science Ltd. Printed in Great Britain

Tsivadze. 2011. Export Diversification in Georgia :Intensive and Extensive Margin. Master Thesis. International School of Economics at Tbilisi State University. Georgia Wendelspiess, R. 2010. Firm Response to Advocacy Campaigns - A Case Study into How Campaigns Stimulate Organizational Change. Dissertation of the University of St. Gallen, Graduate School of Business Administration, Economics, Law and Social Sciences, Switzerland. 